\title{
Colonialism and Institutional Persistence: Mixed Legislative Legacies in Ghana and Kenya*
}

\author{
Ken Ochieng' Opalo ${ }^{\dagger}$
}

November 16, 2021

Forthcoming, Journal of Historical Political Economy

\begin{abstract}
A large literature investigates the institutional legacies of European colonialism around the world. However, in linking contemporary outcomes to colonial antecedents, most works seldom identify specific institutions or their temporal evolution. This paper examines the institutional legacies of colonialism in Africa through the lens of colonial legislatures. Cross-country analyses show that the correlation between colonial antecedents and contemporary measures of legislative institutionalization is tenuous at best and sensitive to measurement. A comparative study of legislative development in Ghana and Kenya explains likely causes of the mixed legacies of colonial legislatures. Beyond colonial institutional design, temporal variation in intra-legislative factional politics explains legislative development in the two countries. This article highlights the importance of understanding the specific mechanisms behind colonial institutional persistence and change.
\end{abstract}

Keywords: Institutions, Colonial Legacies, Legislatures, Ghana, Kenya

${ }^{*}$ I thank Yonatan Morse and participants in the 2019 Annual Conference of the American Political Science Association for comments on earlier drafts of this paper. I also thank Nicole Farber for excellent research assistance. Any errors herein are my own. This research was generously funded by the Mortara Center at Georgetown University.

${ }^{\dagger}$ Walsh School of Foreign Service, Georgetown University. 3700 O Street, NW. Washington, DC 20057 USA; koo6@georgetown.edu 


\section{Introduction}

What explains contemporary variation in levels of legislative institutionalization and strength in postcolonial states? A large literature explores the institutional legacies of European colonialism. ${ }^{1}$ However, many of these works seldom examine specific institutions, the mechanisms behind their organizational evolution over time, or direct links to contemporary outcomes of interest. A common approach tends to be to associate broadly defined bundles of institutions (e.g. property rights) and outcomes of interest (e.g. economic development). While these works have significantly improved our understanding of how institutions shape economic and political development, many outstanding questions remain. ${ }^{2}$ For example, what were the organizational/procedural features of specific colonial institutions such as legislatures, judiciaries, and prefectural bureaucracies? And what factors drove the processes of institutional development both during and after the end of colonial occupation? Answering these questions is important for understanding both institutional development under colonialism and the mechanisms behind postcolonial institutional persistence and change.

Employing a historical institutionalist approach, this article explains the divergent institutional legacies of colonial legislatures in Africa. I argue that colonial institutional design is insufficient in explaining postcolonial legislative development and contemporary variation in levels of legislative institutionalization. This is because the historical evolution of colonial legislatures was marked not by linear persistence, but by change conditional on various contextual social and political realities. Therefore, to understand contemporary variation in legislative institutional features and outcomes in Africa, one must understand the dynamics

\footnotetext{
${ }^{1}$ Mamdani (1996); Acemoglu, Johnson and Robinson (2001); Porta, de Salinas and Shleifer (2008); Hariri (2012); Lankina and Getachew (2012); Owolabi (2015); Juan and Pierskalla (2017); Lee and Paine (2019), and Paine (2019). See Abad and Maurer (2021) for a critical review of persistence studies.

${ }^{2}$ A concept like "proper rights protection" is the product of several distinct institutional variables - such as a functional judiciary, effective legislation and oversight, clear property registries, functional markets, and accountable law enforcement. It is also worth noting that the optimal institutional ecosystem for economic growth and development may vary over time. Therefore, one cannot simply assume, without evidence, that specific colonial institutions established in the late 19th century would be optimal for economic development a century later. This calls for detailed temporal studies of the political economies of specific colonial institutions (e.g. executives, judiciaries, legislatures, field administration, etc.).
} 
that drove temporal legislative development in the region. In particular, it is important to pay close attention to how factional politics shaped elites' incentives to invest in legislative institutionalization during and after colonialism. ${ }^{3}$ More broadly, this article argues that claims about historical institutional persistence must be backed by a clear articulation of the mechanisms behind the endurance of specific institutional structures, practices, and outputs.

I provide two pieces of evidence to support this argument. First, cross-country statistical analyses of de facto and de jure measures of contemporary legislative institutionalization reveal mixed legacies of colonial legislatures in Africa. Overall, the correlation between initial conditions (under colonialism) and a variety of contemporary measures of legislative institutionalization is tenuous at best and sensitive to the choice of measurement. Second, detailed case studies of Ghana and Kenya (both former British colonies) explore potential causes of the mixed legacies of colonial legislatures. Data on membership, tenure, and legislative outputs support the claim that factional politics was critical for temporal institutional development in the two colonies. In both countries, coalition politics during and after the end of colonialism appear to have mattered more for legislative development than initial colonial institutional design.

To highlight the importance of temporal analyses of institutional development, I show that postcolonial legislatures in Africa have undergone significant changes since their colonial origins. While I focus on British colonies, insights herein generalize to other colonial legislatures. Throughout the region, colonial legislatures were purposefully designed to be subordinate to Governors and the metropole. At independence, the same legislatures were dominated by relatively "over-developed" executive branches. However, uncertainty over inter-branch relations occasioned by the critical juncture of decolonization created opportunities for legislative assertiveness. In several cases, arising inter-branch disputes resulted in the closure of legislatures. It was not until the late 1970s that executive-legislative relations in the region

\footnotetext{
${ }^{3}$ This explanation is similar to the finding in (Stasavage, 2003) that it was the representation of creditors in the English parliament (and not institutional structures per se) that guaranteed property rights protection. See also Swenson (2001) and Thelen (2004) on the coalition basis of institutional stability.
} 
began to stabilize, albeit under autocratic single party rule. The re-introduction of multiparty electoral politics in the early 1990s changed executive-legislative relations in the region and caused further divergence in institutional trajectories. Given this history, it becomes clear why accounts that compress the histories of colonial legislative institutions in Africa and elsewhere are necessarily incomplete.

Ghana and Kenya are excellent case studies through which to analyze these dynamics. Both are former British colonies whose legislatures share Westminster origins. They also differ on important dimensions. The Gold Coast (Ghana) was the archetypical "extractive" colony. Never a settler colony, British imperialism in Ghana primarily focused on trade while balancing variously interests in the Gold Coast Colony, the Ashanti Kingdom, and the Northern Territories. The Legislative Council (LegCo) reflected this reality, with its membership composed of representatives of commercial interests, urban municipalities, Chiefs, and appointees of the Governor. Kenya was a settler colony whose Legislative Council (LegCo) was dominated by appointed and elected European immigrants until the late 1950s. Membership in the LegCo was race-based (Africans, Arabs, Europeans, and Indians).

On paper, Ghana's LegCo looked like it would emerge stronger than Kenya's after independence. It was much older; had African membership since its founding in 1850 (almost a century before the first African joined the Kenyan LegCo in 1944); was fairly well-integrated with the precolonial polities in the Gold Coast; and had direct representation for important economic, political, and social actors. Yet, compared to Kenya, Ghanaian independence precipitated relatively high levels of institutional instability, including repeated closure of the legislature (see Figures 4 and 5).

What explains this divergence? The important difference was that throughout its history dominant factions in Kenya's LegCo were institutionalists incentivized to preserve its stature as the main arena for managing intra-elite politics. In contrast, multiple dominant factions in Ghana's LegCo repeatedly saw their power eroded, ultimately resulting in the triumph of an independence coalition whose leadership was anti-institutionalist and willing to replace 
the legislature with the ruling party as the main arena for managing intra-elite politics. Consequently, decolonization was marked by legislative institutional layering and continuity

in Kenya (Hakes, 1970; Gertzel, 1970; Opalo, 2019) and a precipitous discontinuity in Ghana (Arhin, 1985; Allman, 1993; Rathbone, 2000).

This article makes two important contributions. First, it improves our understanding the institutional legacies of colonialism by studying a specific institution - legislatures over time. The focus is on institutional design and specific mechanisms driving institutional persistence and change. Second, it highlights the importance of measurement in persistence studies by showing that correlations between contemporary institutional features and their colonial origins vary across different dimensions of legislative institutionalization. The key takeaway - illustrated by the comparative study of Ghana and Kenya - is that studies that merely link contemporary institutional outcomes to colonial antecedents, without specifying temporal mechanisms of institutional persistence and change, are necessarily incomplete.

\section{Historical Institutionalism and Colonial Legislatures}

My point of departure is that institutions are not self-executing, but reflect the preferences of dominant factions (Stasavage, 2003; Hall, 2009) in conjunction with historically constructed ideas about what institutions do (Sheingate, 2014). Therefore, institutions are likely to persist if their processes and outputs are consistent with the preferences of dominant factions or if dominant factions are forced to abide by them due to established norms or political culture. Therefore, in attributing contemporary outcomes to historical institutions, it is important to account for intra-institutional factional politics and the specific mechanisms driving persistence or change over time. To this end, historical institutionalism, with its emphasis on "how temporal processes and events influence the origin and transformation of institutions" (Fioretos, Falleti and Sheingate, 2016, p. 2), offers a useful analytical lens. Historical institutional analysis can help us understanding how initial conditions shaped colonial institutional 
design, the logics of path-dependence and institutional persistence, as well as the dynamics of temporal institutional change.

Table 1: The Logics of Legislative Institutional Development

\begin{tabular}{|c|c|c|}
\hline Important Variables & $\begin{array}{l}\text { Mechanisms Driving } \\
\text { Institutional } \\
\text { Persistence/Change }\end{array}$ & Observable Measures \\
\hline Timing & $\begin{array}{l}\text { 1) Institutional design 2) } \\
\text { Intra-institutional distribu- } \\
\text { tion of power }\end{array}$ & $\begin{array}{l}\text { 1) Legislative powers 2) Mem- } \\
\text { bership 3) Contours of politi- } \\
\text { cal contestation }\end{array}$ \\
\hline $\begin{array}{l}\text { Nature of Factional } \\
\text { Politics }\end{array}$ & $\begin{array}{l}\text { 1) Support/Opposition to in- } \\
\text { stitutional structures, prac- } \\
\text { tices, and outputs 2) Institu- } \\
\text { tional political independence }\end{array}$ & $\begin{array}{l}\text { 1) Institutional stability 2) } \\
\text { Inter-branch constraints } 3 \text { ) In- } \\
\text { fluence on policy }\end{array}$ \\
\hline $\begin{array}{c}\text { Presence of Historical } \\
\text { Polities }\end{array}$ & $\begin{array}{l}\text { 1) Historical elites' institu- } \\
\text { tional influence 2) Nature of } \\
\text { intra-elite politics } 3 \text { ) Continu- } \\
\text { ity or discontinuity of histori- } \\
\text { cal elites' dominance }\end{array}$ & $\begin{array}{l}\text { 1) Intra-institutional distribu- } \\
\text { tion of power 2) Institutional } \\
\text { inclusion/Exclusion of histori- } \\
\text { cal elites }\end{array}$ \\
\hline Institutional Age & $\begin{array}{l}\text { 1) Level of institutionalization } \\
\text { (corporate identity and inter- } \\
\text { nal differentiation) 2) Embed- } \\
\text { dedness in political economy }\end{array}$ & $\begin{array}{l}\text { 1) Institutional longevity 2) } \\
\text { Organizational capacity 3) In- } \\
\text { stitutional importance in or- } \\
\text { ganizing elite politics }\end{array}$ \\
\hline Colonial Power & $\begin{array}{l}\text { 1) Institutional design 2) } \mathrm{Na}- \\
\text { ture of imperial politics }\end{array}$ & $\begin{array}{l}\text { 1) Influence on policy 2) Con- } \\
\text { tours of legislative politics } 3 \text { ) } \\
\text { Locus of political organizing } \\
\text { and contestation }\end{array}$ \\
\hline Regime Type & $\begin{array}{l}\text { 1) Control over internal oper- } \\
\text { ations (budgets, calendar, leg- } \\
\text { islative agenda) 2) Nature of } \\
\text { executive-legislative relations } \\
\text { 3) Membership }\end{array}$ & $\begin{array}{l}\text { 1) Degree of organizational in- } \\
\text { dependence 2) Nature of inter- } \\
\text { branch relations } 3 \text { ) Influence } \\
\text { on policy }\end{array}$ \\
\hline
\end{tabular}

Notes: Table summarizes important variables that influence legislative institutional development, the key underpinning mechanisms, and associated observable measures.

In the case of colonial legislatures, a number of factors are important for understanding their temporal evolution (see Table 1 for a summary). These factors may interact with each other in various permutations. First, there is time. Scholars of historical institutionalism have shown the importance of time in structuring politics - whereby the probability of realizing 
certain outcomes is dependent on the temporal context (Pierson, 2004; Grzymala-Busse, 2011; Hall, 2016). The introduction of colonial legislatures took place in distinct time periods characterized by well-defined ideas about imperialism, human rights, political participation, and executive-legislative relations. These variables shaped colonial legislative institutional design (and the resultant intra-institutional politics) in unique ways. For example, Wight (1946) shows how the institutional features of English colonial legislatures varied over time - with colonies established in the late 19th century and later having distinctly different institutional features compared to their older counterparts. Early colonial legislatures (in the Atlantic) approximated the idea of responsible government in Westminster. However, from London's perspective, by the mid 19th century the experiment with colonial representative government had largely failed. ${ }^{4}$ Thereafter, colonial legislatures were designed to be weak vis-à-vis Governors, with Officials (appointed representatives of the colonial administration) outnumbering Unofficials (appointed or elected representatives of civilian interests).

Second, institutions are ultimately staffed by individuals representing often contradictory interests. ${ }^{5}$ As such, it is important to understand the role of coalition politics as drivers of institutional persistence and change (Mahoney and Thelen, 2010; Thelen, 2014). This is especially true in the case of legislatures which often represent multiple competing interests. Furthermore, by construction, strong legislatures constrain other branches of government. Therefore, political actors in other branches of government (especially the executive) often face strong incentives to limit legislative strength. Consequently, temporal variation in legislatures' ability to check executive power relies on the presence of dominant factions that

\footnotetext{
${ }^{4}$ The same contestations regarding legislative control over revenue present in 17th century England were also present in the representative assemblies in the West Indies and North America (Wrong, 1923; Watson, 1995; Squire, 2012). For instance, Assembly members in Jamaica went about "arrogating to themselves all functions of government, and denying the (Executive) Council the right to originate not only money bills, but all measures of general policy (Egerton, 1918, p. 210). By 1866 the Jamaican Legislative Council lost its representative character and became an entirely nominated institution.

${ }^{5}$ This observation may apply in the case of individual institutions or an institutional ecosystem. For example, a functional and stable justice system requires the persistence of a coalition of individuals in courts, police, lawyers, and prison systems that are committed to the basic tenets of the rule of law.
} 
are willing to assert legislative authority (Stasavage, 2003). ${ }^{6}$

Besides timing and factional politics, other important factors that may drive colonial legislative development include the presence of precolonial polities, institutional age, the identity of the colonial power, and regime type. The presence of strong precolonial polities may reinforce or destabilize colonial institution-building efforts by structuring intra-elite politics. For example, since institutionalization takes time, temporal changes in the relative power between "traditional" and "modern" elites and resulting contestations over the right to legitimate rule may disrupt the process of institutional development. Legislative institutionalization increases over time as legislatures develop a corporate identity distinct from their environment, undergo internal differentiation, and accumulate institutional culture (Polsby, 1968; Squire, 2012; Opalo, 2019). An old institution is also more likely to be embedded in its socio-political habitat. Once established as the main arena for bargaining over policy, interest groups and other social actors are likely to protect their interests through legislative action. Consequently, quotidian legislative politics often mirrors the wider society's politics. Colonial powers can influence legislative development by externalizing their metropolitan institutions and political culture (albeit with restrictions on colonized populations). Finally, regime type matters in delineating the boundaries of legislative power and membership. Unlike autocracies, democracies are more likely to have free elections and enable legislatures to allocate resources for staff, plenary sessions, committee work, members' remuneration, and research. As such, meaningful legislative institutionalization is more likely to occur under democracy than autocracy.

The empirical record broadly supports these observations. For example, in British colonies political development revolved around the quest for Westminster-style parliamentary supremacy and questions of membership - both regarding the inclusion of non-Europeans and Unofficial majorities (Wight, 1947; Wheare, 1950; Davidson, 1974; Opalo, 2019). In settler majority

\footnotetext{
${ }^{6}$ For more on this see the literature on legislative constraints on executive rule making (Bolton and Thrower, 2016; Opalo, 2020).
} 
colonies, legislatures approximated the Westminster model. In settler minority colonies, the driver of institutional development was contestation over demands for minority European responsible government and independence under majority rule. In non-settler colonies, legislative development featured the balancing of "traditional" authority against the demands of popular electoral politics. ${ }^{7}$ Even when legislatures shared a colonial institutional legacy, institutional development varied conditional on demographics, the presence of organized interests, pre-colonial state histories, prevailing ideas about political representation, and the nature of factional politics within those institutions.

With the above background, it is possible to conceptualize the temporal aspects of colonial legislative institutional design, persistence and change. The timing of the creation of legislatures in colonies shaped the types of legislatures that were created - their membership, internal organization, powers vis-à-vis Governors and the metropole, and general influence over policy. Overall, colonial institutional design reflected metropolitan institutional architectures and the prevailing ideas about political representation, franchise extension, and colonies' capacity for self-rule. Once created, legislative institutions structured the distribution of power among dominant elite factions within them, thereby defining the contours of continued institutional development. Because institutionalization takes time, ceteris paribus, temporal permanence of dominant factions was more conducive to institutional development and stability. The next section examines these concepts in the context of African states.

\section{Colonial Legislatures in Africa}

Timing and intra-institutional factional politics mattered for legislative development in Africa. By the time European imperial powers formally established colonies in Africa, nearly

\footnotetext{
${ }^{7}$ Fletcher-Cooke (1966) makes the case for distinguishing between "those parts of the Commonwealth to which the Westminster model went as 'accompanied baggage' and those parts to which it was sent as an "export"' (p. 145). In many colonies, demographics (especially European population share), shaped colonial legislative development (Paine, 2019).
} 
all of them had centuries of experience with colonial government in the Atlantic "New World." Among British colonies, the institution of the Legislative Council had undergone significant evolution from its introduction in the Caribbean (Wight, 1946; Burns, 1966). The French, too, had accumulated similar experience within their overseas possessions (James, 1938). ${ }^{8}$ These earlier experiences informed legislative institutional design in Africa. Invariably, colonial powers established legislatures that were subordinate to Governors. Yet despite these shared elements of institutional design, the continued evolution of colonial legislatures in Africa partially depended on the patterns of factional politics within specific territories.

\subsection{Variation Within and Across Empires}

Both within and across imperial powers, colonial legislatures in African territories varied on several dimensions - including the timing of their introduction, membership, mode of constitution, and institutional powers. Overall, British colonial administrations created legislatures earlier than other imperial powers (see Figure 1 (a)). At independence, most French colonies had only experienced territorial legislatures for 14 years. British colonies averaged over 60 years - varying from 8 years in Sudan to 154 years in Sierra Leone. In contrast to the British and French colonial experience, the Democratic Republic of Congo's legislature (a Belgian colony) was established right before independence in 1960. Because institutionalization takes time, former British colonies were, on average, less likely to experience a breakdown of executive-legislative relation and the closure of legislatures after independence (Figure 1 (b)) and more likely to experience improvements in legislative strength after independence (Figure 3). The longer experience with legislatures socialized elites and structured territorial political economies in ways that fostered postcolonial institutional stability. ${ }^{9}$ Other

\footnotetext{
${ }^{8}$ The other colonial powers in Africa, Belgium, Germany, Italy, Portugal, and Spain, held few territories and had limited experience with colonial legislatures. As such, this paper primarily uses examples from British and French colonies.

${ }^{9}$ Cartwright (1970) provides an excellent case study of Sierra Leone - which is a "hard case" in the sense that its legislative institution survived the tumultuous politics of the late 1960s (after a brief closure) and descent into autocracy. See also Opalo (2019) and Hayward (1984).
} 
outcomes showed mixed results. For example, legislatures with a British legacy historically enjoyed fewer budgetary powers but more investigative powers (Figure 2).

Figure 1: Share of (Former) Colonies With Functional Legislatures
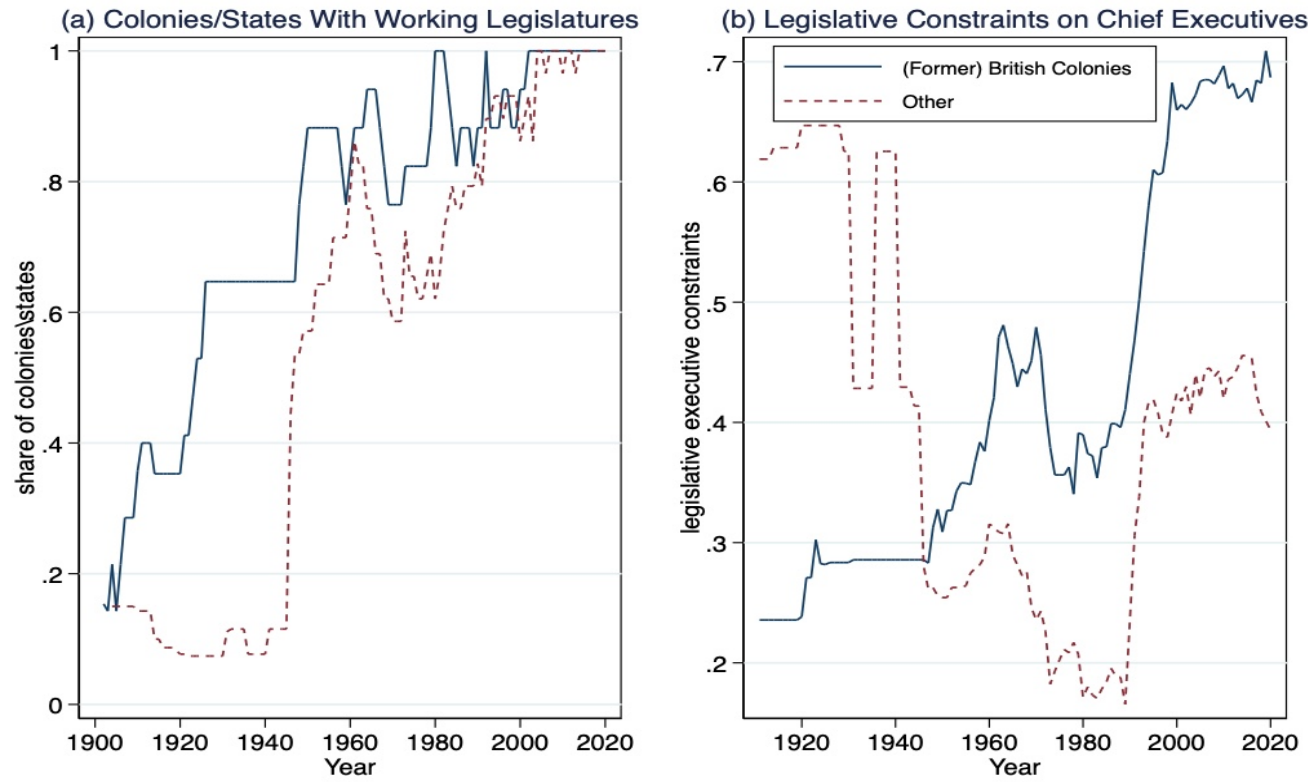

Notes: Figures show (a) trends in the share of colonies with functional legislatures and (b) levels of legislative executive constraints. British colonies acquired territorial legislatures earlier and were less likely to experience legislative closure following independence. They also imposed more constraints on executives after independence. Data from (Coppedge et al., 2021)

Institutional design shaped intra-legislative distribution of power and elite political behavior. Consider French colonies. France espoused direct rule and a policy of "assimilation" that enabled direct representation in Paris (Lewis, 1962; Cooper, 2014). Its colonies were consolidated into two federations (French West Africa and French Equatorial Africa). This institutional structure shaped the distribution of power and subsequent elite incentives. The loci of contestation over representation, policies, and future independence were not at the territorial level, but at the federation level and in Paris. Leading African politicians in French colonies chose to serve as representatives in Paris - leading to the stunting of legislative institutional development in their home territories (Morgenthau, 1964; Opalo, 2019). ${ }^{10}$ In

\footnotetext{
${ }^{10}$ Future presidents like Leopold Senghor (Senegal), Hubert Maga (Benin), Félix Houphouet-Boigny (Côte d'Ivoire), Hamni Diori (Niger), and Modibo Keïta of Mali all served in the National Assembly in Paris.
} 
Figure 2: Legislative Strength Across (Former) Colonies
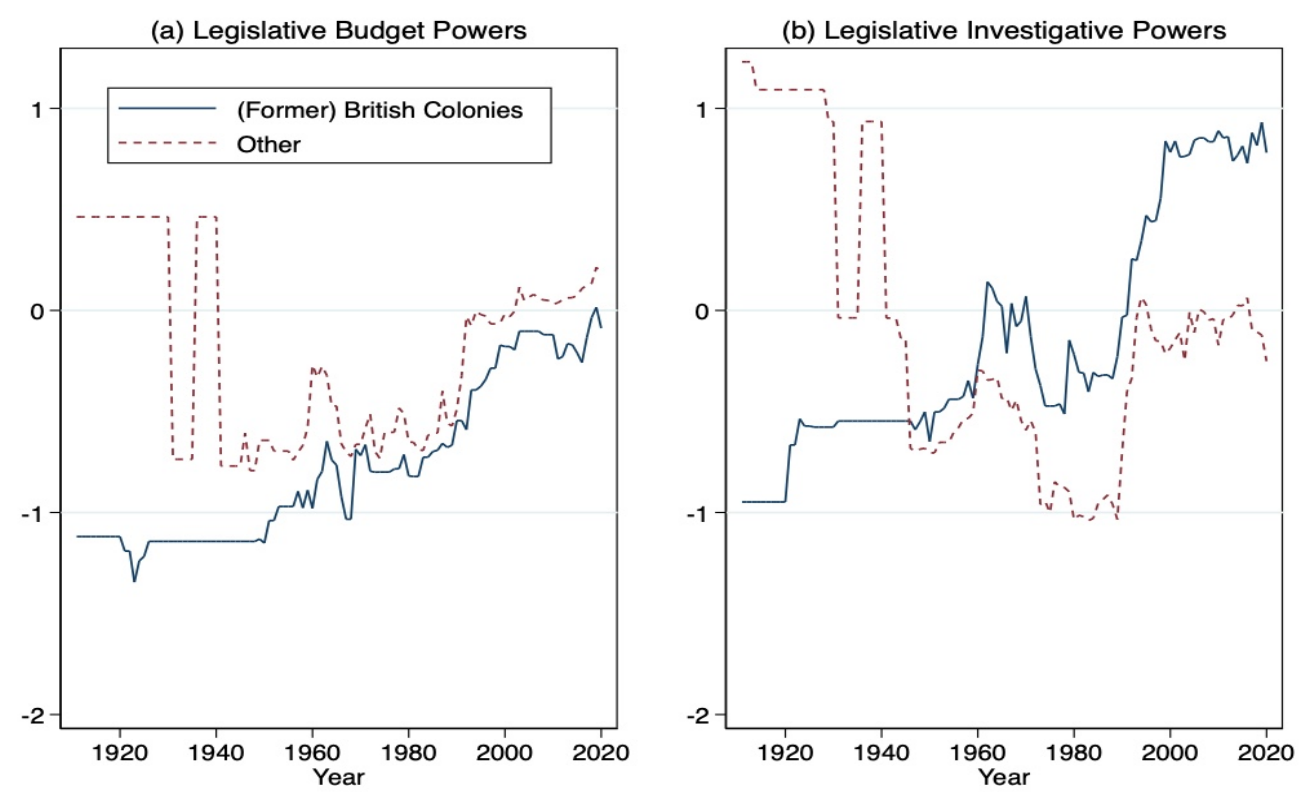

Notes: Figures show (a) trends in legislative budget powers and (b) legislative investigative powers. Where legislatures existed, those with a Westminster inheritance have, on average, had relatively lower budgetary powers but more investigative powers. Data from (Coppedge et al., 2021)

most French colonies territorial legislatures were only established in 1946. Other non-British colonies had equally late starts regarding legislative development. This partially explains the patterns in Figures 1 (b) and 2 (b).

British colonialism produced different patterns of intra-institutional distribution of power. ${ }^{11}$ Its colonies had territorial LegCos, there was no representation at Westminster, indirect rule and greater emphasis on local government empowered "traditional" elites wherever they existed, and membership was initially restricted to Europeans or wealthy Africans (Ross, 1927; Wight, 1947; Wheare, 1950; Wylie, 1977). Furthermore, despite the restricted powers of Legislative Councils, the Westminster tradition provided a model that Africans and Europeans alike aspired to in their quest to maximize their power and influence over policy (Davidson, 1974). As such, former British colonies were more likely to have older legislatures at indepen-

\footnotetext{
${ }^{11}$ While acknowledging, like (Kiwanuka, 1970), that colonialism was uniformly rapacious regardless of the identity of the imperial power, the argument here is with regard to elite institutions and not everyday experiences of colonized populations.
} 
Figure 3: Correlation Between Past and Present Levels of Executive Constraints

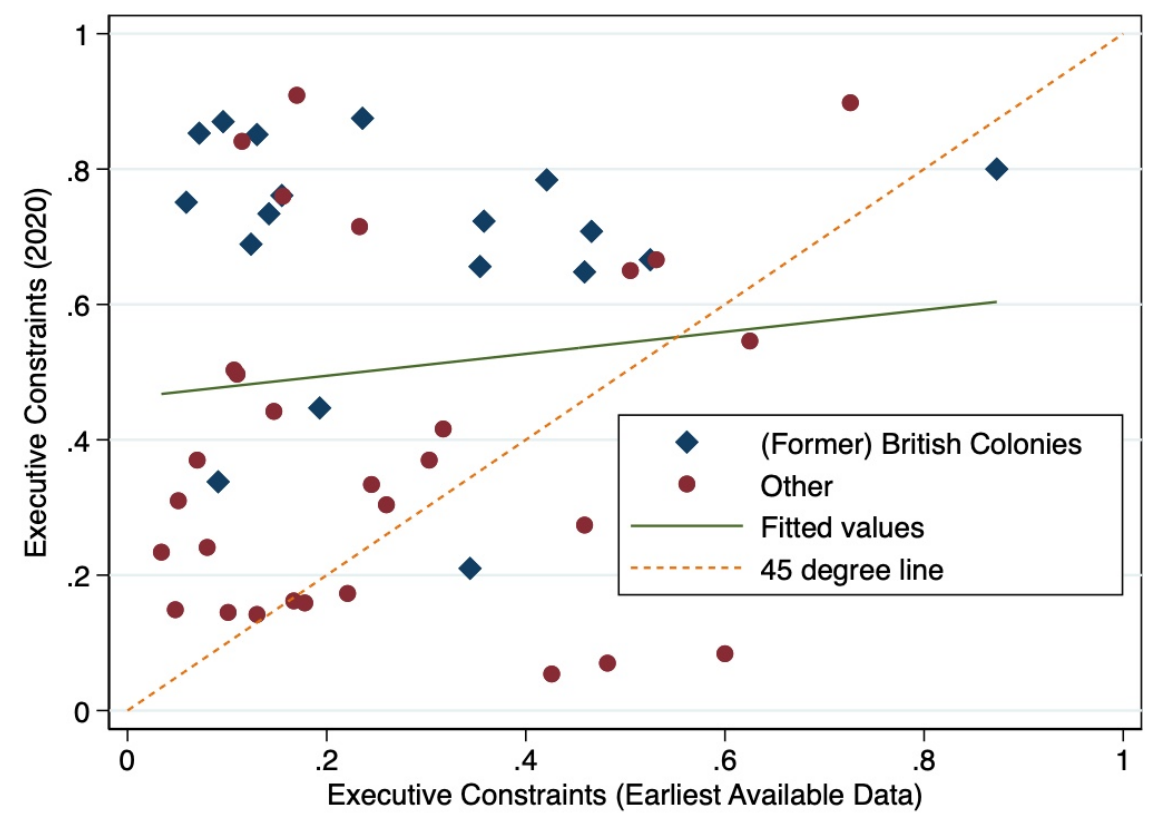

Notes: Figure shows the correlation between past (earliest available data under colonial rule) and present (2020) levels of legislative executive constraints. Most legislatures have become stronger since their funding, with former British colonies experiencing greater advances. Data from (Coppedge et al., 2021)

dence. Their legislatures were also more likely to be anchored in local political economies hence the relatively reduced risk of postcolonial breakdown of executive-legislative relations (Figure 1 (a)) and better record of postcolonial development (Figure 3). ${ }^{12}$

The idea that institutions distribute power and determine where and how elites bargain over policies is worth examining more closely. In both British and French colonies, Africans harbored broadly similar grievances. However, differences in the locus power within the colonial legislative system determined where leading African political elites focused their attention. In French colonies, power resided in Paris, while in British colonies it was in the territorial Legislative Councils. This means that the latter institutions could cultivate habits of how legislatures work within their respective political economies over time. An observable implication of this claim is that, ceteris paribus, legislatures in British former colonies - which

\footnotetext{
${ }^{12}$ The only British colonies to attempt federation were Northern Rhodesia (Zambia), Southern Rhodesia (Zimbabwe), and Nyasaland (Malawi), which formed the Central African Federation under between 19531963 (Rotberg, 2008). However, the federation was created well after the territorial Legislative Councils in the three colonies were well established and was bitterly opposed by Africans (Opalo, 2019).
} 
tended to be older - were more likely to be institutionalized. ${ }^{13}$ Figures 1, 2, and 3 provide suggestive evidence to support this claim. Around the critical juncture of independence in the 1960s, former British colonies were less likely to experience the closure of legislatures as postcolonial elites vied to recalibrate executive-legislative relations. They were also more likely to register postcolonial improvements in the ability to constrain chief executives.

The dynamics that drove legislative institutional development during colonialism were also present in the postcolonial era. The timing of independence in the 1960 s meant that departing colonial empires superimposed veneers of democracy onto inherently autocratic legislative institutions. Hurriedly codified constitutions established elections with universal suffrage, legislative independence, and electoral systems in the image of imperial powers. In many cases this rapid transition produced postcolonial institutional instability (Figure 1). The trajectories of postcolonial legislative development depended on factional politics at independence. In some countries, the dominant independence factions were different from those that held sway under colonialism (Mamdani, 1996). These countries were more likely to experience discontinuous institutional change and instability at independence. In other countries the same factions bridged the gap between colonialism and independence, thereby facilitating gradual change. The emerging regime types and postcolonial executives' ability to effectively dominate factional politics among elites structured their willingness to tolerate legislative functional autonomy (Opalo, 2019). Finally, moderating all these processes was the level of institutionalization of colonial legislatures at independence. The age of legislatures conditioned the ease with which postcolonial elites could change institutional habits and individual elites' mental models of how legislatures work.

\footnotetext{
${ }^{13}$ Time is an important variable for the process of institutional consolidation (Huntington, 1965; Pierson, 2004). See Polsby (1968) on the processes that underpin legislative institutionalization.
} 


\subsection{Different Measures, Different Legacies}

The above discussion illustrates the complexity of the specific mechanisms that drove legislative institutional persistence and change during and after colonialism. To further illustrate this point, this section provides cross-country evidence of the mixed contemporary legacies of colonial legislative institutionalization by exploring the correlates of both de jure and de facto levels of legislative institutionalization. The point is that, because of the complicated mechanisms driving legislative development, studies that compress history by merely linking colonial institutional design to contemporary outcomes are incomplete. Table 2 summarizes the key variables of interest. ${ }^{14}$

For de jure measures, I use data from Fish and Kroenig (2009) on constitutional provisions for legislative influence on the executive, specific legislative powers, legislative autonomy, and legislative capacity. I also use their aggregate parliamentary powers index (PPI). I analyze both the PPI and its component measures. I augment these data with the measure of legislative powers as coded by the Comparative Constitutions Project. ${ }^{15}$ For de facto measures, I use data from Coppedge et al. (2021) on legislative constraints on the executive, investigative powers, and budget powers. To explore the correlates of legislative power of the purse, I use the International Budget Partnership's legislative open budget index. ${ }^{16}$

I regress indicators of legislative institutionalization on various correlates, including legislative age at independence (measured in years), identity of colonial power, average GDP level, average population, the share of years since independence in which a country had a functional legislature, indicator of state antiquity (up to 1850), the degree of ethnic frac-

\footnotetext{
${ }^{14}$ Data on legislative age since independence are from Opalo (2019). GDP and population data are from Heston, Summers and Aten (2002) and averaged between independence and 2000. Data on the share of years between independence and 2000 with functional legislatures are from Cheibub, Gandhi and Vreeland (2010). State antiquity data are from Bockstette, Chanda and Putterman (2002). Ethnic fractionalization data are from Alesina et al. (2003). Finally, data on level of democratization (polity 2) are from Marshall and Jaggers (2009) and averaged between independence and the year 2000.

${ }^{15}$ See here https://comparativeconstitutionsproject.org/

${ }^{16}$ See here: https://www.internationalbudget.org/. Data from 2017 Open Budget Survey.
} 
Table 2: Summary statistics

\begin{tabular}{|c|c|c|c|c|c|}
\hline Variable & Mean & Std. Dev. & Min. & Max. & $\mathbf{N}$ \\
\hline \multicolumn{6}{|c|}{ de jure Legislative Powers } \\
\hline Legislative Powers & 0.291 & 0.093 & 0.1 & 0.48 & 49 \\
\hline Parliamentary Powers Index (PPI) & 0.385 & 0.123 & 0 & 0.66 & 43 \\
\hline Influence on Exec. & 0.292 & 0.211 & 0 & 0.889 & 43 \\
\hline Specific Powers & 0.32 & 0.157 & 0 & 0.75 & 43 \\
\hline Institutional Autonomy & 0.426 & 0.195 & 0 & 0.889 & 43 \\
\hline Institutional Capacity & 0.543 & 0.167 & 0 & 0.833 & 43 \\
\hline \multicolumn{6}{|c|}{ de facto Legislative Powers } \\
\hline Executive Constraints & 0.506 & 0.272 & 0.054 & 0.909 & 47 \\
\hline Investigative Powers & 0.144 & 1.167 & -2.282 & 2.417 & 47 \\
\hline Power Over Funds & 0.08 & 0.988 & -2.01 & 1.936 & 45 \\
\hline Legislative Open Budget Index (OBI) & 39.367 & 13.895 & 8.333 & 77.75 & 35 \\
\hline \multicolumn{6}{|c|}{ Correlates of Legislative Institutionalization \& Strength } \\
\hline Legislative Age & 46.234 & 40.269 & 0 & 186 & 47 \\
\hline British Colonies & 0.396 & 0.494 & 0 & 1 & 48 \\
\hline Mean GDP (logged) & 8.741 & 1.432 & 5.355 & 12.204 & 46 \\
\hline Mean Population & 6.918 & 10.142 & 0.058 & 58.325 & 46 \\
\hline Open Legislatures (\% years) & 0.765 & 0.237 & 0.31 & 1 & 47 \\
\hline State History & 29.658 & 10.964 & 0 & 50 & 41 \\
\hline Ethnic Fractionalization & 0.632 & 0.25 & 0.036 & 0.925 & 45 \\
\hline Mean Polity & -4.158 & 4.442 & -9 & 9.391 & 45 \\
\hline
\end{tabular}

tionalization, and the polity 2 score. ${ }^{17}$ In line with the discussion above, legislative age at independence and identity of the colonial power are the main independent variables. ${ }^{18} \mathrm{I}$ also employ several control variables. Economic development (proxied by GDP) may foster political stability. Countries with high levels of ethnic fractionalization and large populations are likely to have difficult population geographies, thereby resulting in political instability (Alesina et al., 2003). Having an open and functional legislature is likely to increase the accumulated stock of legislative institutionalization and strength. Finally, I control for state

\footnotetext{
${ }^{17}$ In the Online Appendix (Section 1), I provide graphical illustrations of the bivariate relationships between legislative age and indicators of legislative strength.

${ }^{18}$ Legislative age at independence captures the accumulated stock of experience under colonialism before the institutions were subjected to postcolonial institutional instability shown in Figures 1 and 2.
} 
Table 3: Correlates of de jure Postcolonial Legislative Strength and Institutionalization

\begin{tabular}{|c|c|c|c|c|c|c|c|c|}
\hline & $\begin{array}{c}(1) \\
\text { Powers }\end{array}$ & $\begin{array}{c}(2) \\
\text { Powers }\end{array}$ & $\begin{array}{l}(3) \\
\text { PPI }\end{array}$ & $\begin{array}{l}(4) \\
\text { PPI }\end{array}$ & $\begin{array}{c}(5) \\
\text { Influence }\end{array}$ & $\begin{array}{c}(6) \\
\text { Leg. Powers }\end{array}$ & $\begin{array}{c}(7) \\
\text { Autonomy }\end{array}$ & $\begin{array}{c}(8) \\
\text { Capacity }\end{array}$ \\
\hline Leg. Age & $\begin{array}{c}-0.000553 \\
(-1.80)\end{array}$ & $\begin{array}{c}-0.000225 \\
(-0.52)\end{array}$ & $\begin{array}{c}0.00110^{*} \\
(2.10)\end{array}$ & $\begin{array}{c}0.00123^{*} \\
(2.62)\end{array}$ & $\begin{array}{c}0.00121 \\
(1.05)\end{array}$ & $\begin{array}{c}0.000478 \\
(0.48)\end{array}$ & $\begin{array}{c}0.00264^{* * *} \\
\quad(3.83)\end{array}$ & $\begin{array}{c}0.000160 \\
\quad(0.26)\end{array}$ \\
\hline British Colonies & $\begin{array}{c}-0.0229 \\
(-0.71)\end{array}$ & $\begin{array}{c}-0.0352 \\
(-0.74)\end{array}$ & $\begin{array}{c}-0.0218 \\
(-0.63)\end{array}$ & $\begin{array}{c}-0.0678 \\
(-1.76)\end{array}$ & $\begin{array}{c}0.0531 \\
(0.68)\end{array}$ & $\begin{array}{c}-0.135^{*} \\
(-2.45)\end{array}$ & $\begin{array}{c}-0.224^{* *} \\
(-3.41)\end{array}$ & $\begin{array}{c}0.0762 \\
(1.49)\end{array}$ \\
\hline Mean GDP (log) & $\begin{array}{c}-0.00219 \\
(-0.10)\end{array}$ & $\begin{array}{c}0.00943 \\
(0.33)\end{array}$ & $\begin{array}{c}0.0101 \\
(0.34)\end{array}$ & $\begin{array}{c}0.00993 \\
(0.33)\end{array}$ & $\begin{array}{c}0.0101 \\
(0.18)\end{array}$ & $\begin{array}{c}0.0136 \\
(0.23)\end{array}$ & $\begin{array}{c}-0.0151 \\
(-0.37)\end{array}$ & $\begin{array}{c}0.0416 \\
(0.95)\end{array}$ \\
\hline Mean Pop. & & $\begin{array}{c}0.00213 \\
(1.45)\end{array}$ & & $\begin{array}{c}0.00205 \\
(1.38)\end{array}$ & $\begin{array}{c}0.00203 \\
(0.59)\end{array}$ & $\begin{array}{c}-0.00109 \\
(-0.49)\end{array}$ & $\begin{array}{c}0.00351 \\
(1.48)\end{array}$ & $\begin{array}{c}0.00380 \\
(1.79)\end{array}$ \\
\hline Leg. Open & & $\begin{array}{c}-0.0537 \\
(-0.63)\end{array}$ & & $\begin{array}{c}-0.0508 \\
(-0.66)\end{array}$ & $\begin{array}{c}-0.0664 \\
(-0.48)\end{array}$ & $\begin{array}{c}-0.0846 \\
(-0.49)\end{array}$ & $\begin{array}{l}-0.119 \\
(-1.02)\end{array}$ & $\begin{array}{l}0.102 \\
(0.89)\end{array}$ \\
\hline State Hist. & & $\begin{array}{c}0.00123 \\
(0.86)\end{array}$ & & $\begin{array}{c}0.00183 \\
(1.30)\end{array}$ & $\begin{array}{c}0.00148 \\
(0.61)\end{array}$ & $\begin{array}{c}-0.00125 \\
(-0.51)\end{array}$ & $\begin{array}{c}0.00545 \\
(1.86)\end{array}$ & $\begin{array}{c}0.00105 \\
(0.41)\end{array}$ \\
\hline Ethfrac & & $\begin{array}{c}0.0493 \\
(0.65)\end{array}$ & & $\begin{array}{c}-0.0821 \\
(-1.14)\end{array}$ & $\begin{array}{l}-0.214 \\
(-1.12)\end{array}$ & $\begin{array}{c}-0.0216 \\
(-0.19)\end{array}$ & $\begin{array}{c}-0.00631 \\
(-0.06)\end{array}$ & $\begin{array}{c}-0.0703 \\
(-0.73)\end{array}$ \\
\hline Pollity 2 & & $\begin{array}{c}-0.00129 \\
(-0.25)\end{array}$ & & $\begin{array}{c}0.00928 \\
(1.94)\end{array}$ & $\begin{array}{c}0.0195 \\
(1.91)\end{array}$ & $\begin{array}{c}0.00617 \\
(1.23)\end{array}$ & $\begin{array}{c}0.0101 \\
(1.83)\end{array}$ & $\begin{array}{c}-0.00333 \\
(-0.73)\end{array}$ \\
\hline Constant & $\begin{array}{l}0.339^{*} \\
(2.04)\end{array}$ & $\begin{array}{l}0.189 \\
(0.92)\end{array}$ & $\begin{array}{l}0.280 \\
(1.26)\end{array}$ & $\begin{array}{l}0.354 \\
(1.56)\end{array}$ & $\begin{array}{l}0.360 \\
(0.85)\end{array}$ & $\begin{array}{l}0.411 \\
(1.00)\end{array}$ & $\begin{array}{l}0.465 \\
(1.45)\end{array}$ & $\begin{array}{l}0.111 \\
(0.34)\end{array}$ \\
\hline Countries & 43 & 37 & 40 & 36 & 36 & 36 & 36 & 36 \\
\hline
\end{tabular}

$t$ statistics in parentheses

${ }^{*} p<0.05,{ }^{* *} p<0.01,{ }^{* * *} p<0.001$

Ordinary Least Squares (OLS) regression with robust standard errors in parentheses. The dependent variables are legislative powers (Columns 1-2) as coded in the Comparative Constitutions Project (https:// comparativeconstitutionsproject.org/); and various measures of legislative strength (Columns 3-8) as coded in Fish and Kroenig (2009). These include the aggregate measure of Parliamentary Powers Index and disaggregated components (Columns 5-8) - influence on the executive, enumerated specific powers, autonomy of the legislative branch, and capacity as indicated through formal access to financial and human capital resources.

antiquity - which Hariri (2012) shows is negatively correlated with the entrenchment of European colonial institutions.

I begin by examining the correlates of de jure legislative institutionalization and strength. In Table 3, it is clear that the impact of legislative age and the identity of the colonial power varies by the measure of legislative strength. Legislative age (Leg.Age) at independence is 
Table 4: Correlates of de facto Postcolonial Legislative Strength and Institutionalization

\begin{tabular}{lcccccc}
\hline & $(1)$ & $(2)$ & $(3)$ & $(4)$ & $(5)$ & $(6)$ \\
& Constraints & Constraints & Investigations & Funds & Leg. OBI & Leg. OBI \\
\hline Leg. Age & 0.00103 & 0.000455 & 0.000876 & 0.00617 & -0.0438 & -0.00115 \\
& $(1.22)$ & $(0.34)$ & $(0.15)$ & $(1.49)$ & $(-0.60)$ & $(-0.01)$ \\
British Colonies & $0.316^{* * *}$ & $0.264^{* *}$ & $1.071^{*}$ & $-0.947^{* *}$ & 6.027 & 2.054 \\
& $(4.48)$ & $(2.87)$ & $(2.74)$ & $(-3.04)$ & $(1.10)$ & $(0.27)$ \\
Mean GDP (log) & -0.0769 & -0.0886 & -0.312 & -0.00694 & 2.927 & 2.457 \\
& $(-1.80)$ & $(-1.71)$ & $(-1.39)$ & $(-0.02)$ & $(0.53)$ & $(0.53)$ \\
Mean Pop. & & -0.00157 & -0.00798 & 0.0174 & & 0.258 \\
& & $(-0.42)$ & $(-0.48)$ & $(1.13)$ & & $(1.49)$ \\
Leg. Open & & 0.110 & 0.00428 & 0.451 & & 7.121 \\
& & $(0.53)$ & $(0.00)$ & $(0.67)$ & & $(0.55)$ \\
State Hist. & & -0.00368 & -0.0169 & -0.0254 & & 0.306 \\
Ethfrac & $(-1.06)$ & $(-0.96)$ & $(-2.04)$ & & $(1.12)$ \\
& & 0.0695 & 0.499 & 0.884 & & 2.312 \\
Polity 2 & $(0.38)$ & $(0.53)$ & $(1.53)$ & & $(0.17)$ \\
& & 0.0122 & 0.0355 & 0.0315 & & 0.800 \\
Constant & & $(1.35)$ & $(0.91)$ & $(0.79)$ & & $(0.95)$ \\
& $0.936^{* *}$ & $1.130^{*}$ & 2.545 & 0.226 & 17.14 & 6.616 \\
Countries & $(2.87)$ & $(2.37)$ & $(1.08)$ & $(0.11)$ & $(0.42)$ & $(0.18)$ \\
\hline
\end{tabular}

$t$ statistics in parentheses

${ }^{*} p<0.05,{ }^{* *} p<0.01,{ }^{* * *} p<0.001$

Ordinary Least Squares regression with robust standard errors in parentheses. The dependent variables include measures of legislative constraints on the executive (Columns 1-2) and legislative investigative (3) and budgetary powers (4) as coded by Coppedge et al. (2021). The dependent variable in Columns 5-6 is the aggregate indicator of legislative influence over the budget process as coded by the International Budget Partnership Project (https://www.internationalbudget.org/).

positively correlated with the aggregate PPI, as well as legislative autonomy. At the same time, British legislative heritage is negatively correlated with constitutional legislative powers and autonomy - likely due to the lack of separation of powers in Westminster systems. I then explore the correlates of de facto legislative institutionalization and strength in Table 4. The results suggest that the correlation between legislative age at independence and 
de facto indicators of legislative powers is statistically indistinguishable from zero. British colonial heritage is positively correlated with levels of constraints on executives as well as investigative powers and negatively correlated with control over government funds. Overall, the observable persistent impacts of colonial legislatures are tenuous at best and appear to vary by the choice of measurement of contemporary institutional features.

The results in Tables 3 and 4 do not necessarily imply that colonial legacies do not matter. Instead, they reflect the realities of temporal institutional development - which in some cases has resulted in convergence of both de jure and de facto indicators of legislative institutionalization and strength in Africa. As such, to fully understand the relationship between colonial institutional design and contemporary outcomes one must examine the histories of specific legislatures and their evolution over time. It is not enough to assume linear institutional persistence. The next section examines the historical evolution of the Ghanaian and Kenyan legislatures with a view to highlighting the sources of temporal legislative divergence between the two countries despite a shared colonial institutional heritage.

\section{The Legacies of Colonial Legislatures in Ghana and Kenya}

The histories of legislative development in Ghana and Kenya illustrate the importance of temporal analyses of institutional persistence and change. Both are former British colonies with a shared institutional design and whose Legislative Councils were designed to be subordinate to Governors (Bertram, 1930; Wight, 1946, 1947; Burns, 1966; Hakes, 1970; Opalo, 2019). ${ }^{19}$ However, despite their common institutional origins, the two countries' legislatures have had significantly different postcolonial trajectories. At independence in 1957, Ghana's LegCo had accumulated 107 years of experience compared to Kenya's 56 years in 1963. Its

\footnotetext{
${ }^{19}$ The Legislative Councils in Ghana and Kenya were designed to be dominated the respective Governors through the Official majority. As Bertram (1930) observes, "[t]he effect of this official majority is that the Legislative Council [was] an advisory body" (p. 168) lacking the institutional powers to compel colonial administrations to action. That said, the mere presence of Unofficials in Legislative Councils served to structure the direction of political development and policy outcomes in British colonies.
} 
long history notwithstanding, beginning in 1966 Ghana's legislature experienced multiple closures due to coups and generalized elite political instability. In total, the Ghanaian legislature was closed for 42 percent of the time between 1957 and 2008. Kenya's legislature was open the entire time. ${ }^{20}$

Yet as is shown in Table 5 and Figures 4 and 5, the two legislatures have since converged on some indicators of legislative strength, albeit with higher institutional volatility in Ghana's legislature and slightly better outcomes in Kenya. The institutional histories of the two legislatures and the summaries in Table 5 show that a simple analysis linking contemporary institutional features of the two legislatures to colonial institutional design would miss important facts about the temporal evolution of the two institutions. As a corollary, their relative contemporary rankings are conditional on the choice of measurement.

\subsection{Similar Origins, Different Histories}

What explains postcolonial legislative institutional volatility in Ghana and stability in Kenya? The answer to this question lies in the timing of institutional design and the resultant elite factional politics in the two countries' colonial Legislative Councils. In Ghana, the leading Unofficial African coalitions anchoring legislative institutional development shifted over time from merchants (1850-1898), to high-status barristers (1898-1925), to chiefs (1925-1951), and finally to educated "commoners" (1951-1957). Given that institutionalization takes time, these changes disrupted the process of legislative development - hence Ghana's postcolonial legislative institutional volatility. In Kenya, Unofficial politics was dominated by Europeans from 1907 until the advent of elected African representation in 1957. Furthermore, the gradual increase in African representation yielded an institutionalist dominant coalition that together with moderate Europeans midwifed independence in 1963 and thereafter presided over legislative institutional continuity.

\footnotetext{
${ }^{20}$ See Figure ?? in the Appendix
} 
Below I expound upon these claims with a focus on institutional design and shifts in factional politics. The primary goal of this exercise is not to provide a unified theory of colonial legislative institutional development. Instead, it is to highlight the importance of studying the underlying drivers of temporal evolution of colonial legislatures, rather than simply assuming linear institutional persistence. The importance of doing so is underscored by the Kenyan legislature's better postcolonial performance despite the fact that, on paper, its Ghanaian counterpart seemed more institutionalized in the late colonial period.

Table 5: Features of Ghanaian and Kenyan Legislatures

\begin{tabular}{|c|c|c|}
\hline Variable & Ghana & Kenya \\
\hline \multicolumn{3}{|c|}{ de jure Legislative Powers } \\
\hline Legislative Powers & .29 & .29 \\
\hline Parliamentary Powers Index (PPI) & .47 & .31 \\
\hline Influence on Executive & .4444444 & .3333333 \\
\hline Specific Powers & .5 & .125 \\
\hline Institutional Autonomy & .4444444 & .1111111 \\
\hline Institutional Capacity & .5 & .8333333 \\
\hline \multicolumn{3}{|c|}{ de facto Legislative Powers } \\
\hline Executive Constraints & .851 & .875 \\
\hline Investigative Powers & 1.193 & 1.664 \\
\hline Power Over Funds & .641 & 1.371 \\
\hline Legislative Open Budget Index (OBI) & 38.75 & 41.6667 \\
\hline
\end{tabular}

Legislative Powers are according to the constitutions of Ghana (1992) and Kenya (2010) as coded in the Comparative Constitutions Project (https://comparativeconstitutionsproject.org/. The PPI and its disaggregated components are from Fish and Kroenig (2009). Data on executive constraints, investigative powers, and power over funds are from 2020 as coded by Coppedge et al. (2021). The Legislative OBI data are from 2017 as coded by the International Budget Partnership (https://www.internationalbudget.org/

The Gold Coast Legislative Council (LegCo) was founded in 1850 with the typical characteristics of legislatures in Crown Colonies. Reflecting the distribution of political power at the time, its Unofficials represented African and British trading, banking, and mining interests. More often than not the "mercantile and administrative interests often coincided" 
(Bly, 1982, p. 257). Eventually, the administration expanded membership to include Chiefs and representatives of urban residents. The inclusion of Chiefs redistributed institutional power away from the merchants and the new educated elites representing urban areas. This development opened up an intra-elite cleavage that would structure Ghanaian politics well into independence. Chiefs began to influence legislative politics in the early 1900s until finally losing power in 1951. I argue that the temporal shifts in the dominant legislative coalitions in the Gold Coast - especially the manner and rapidity with which Chiefs lost power in the LegCo - planted the seeds of postcolonial legislative institutional instability in Ghana. ${ }^{21}$

Figure 4: Trends in Legislative Strength in Ghana and Kenya

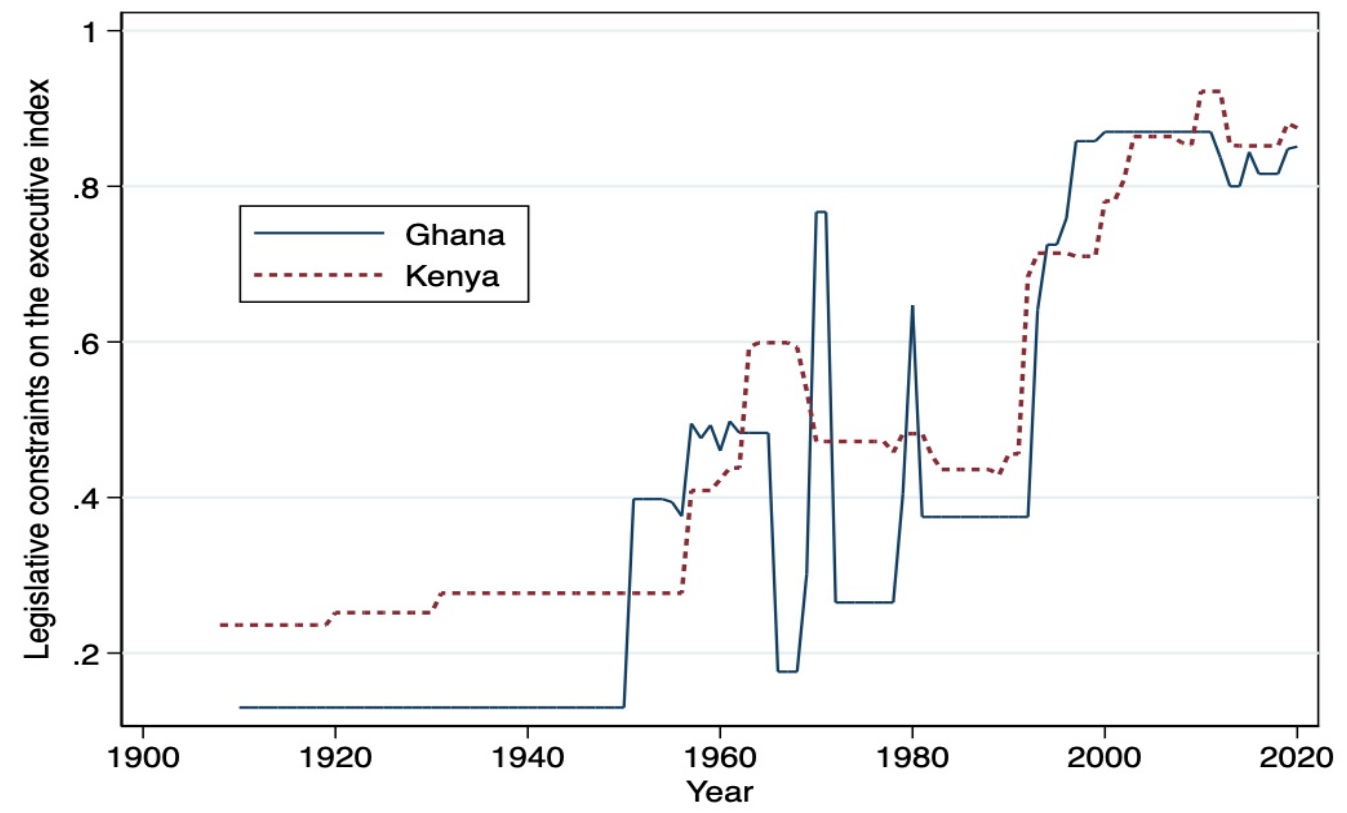

Notes: Figure shows trends in legislative constraints on chief executives in Ghana and Kenya. Notice the institutional volatility in Ghana. Data from Coppedge et al. (2021).

In Kenya, the legislature was dominated by European immigrants between 1907 and 1961. The first African member of the legislature was appointed in 1944. Elections were introduced in 1920 for non-Africans, with African electoral representation becoming a reality in 1958. The expansion of African representation was marked by continuity rather than radical change. In the process of decolonization, a split emerged among both European immigrants

\footnotetext{
${ }^{21}$ In the Online Appendix (Section 2.1) I discuss potential alternative explanations.
} 
Figure 5: Trends in Legislative Strength in Ghana and Kenya
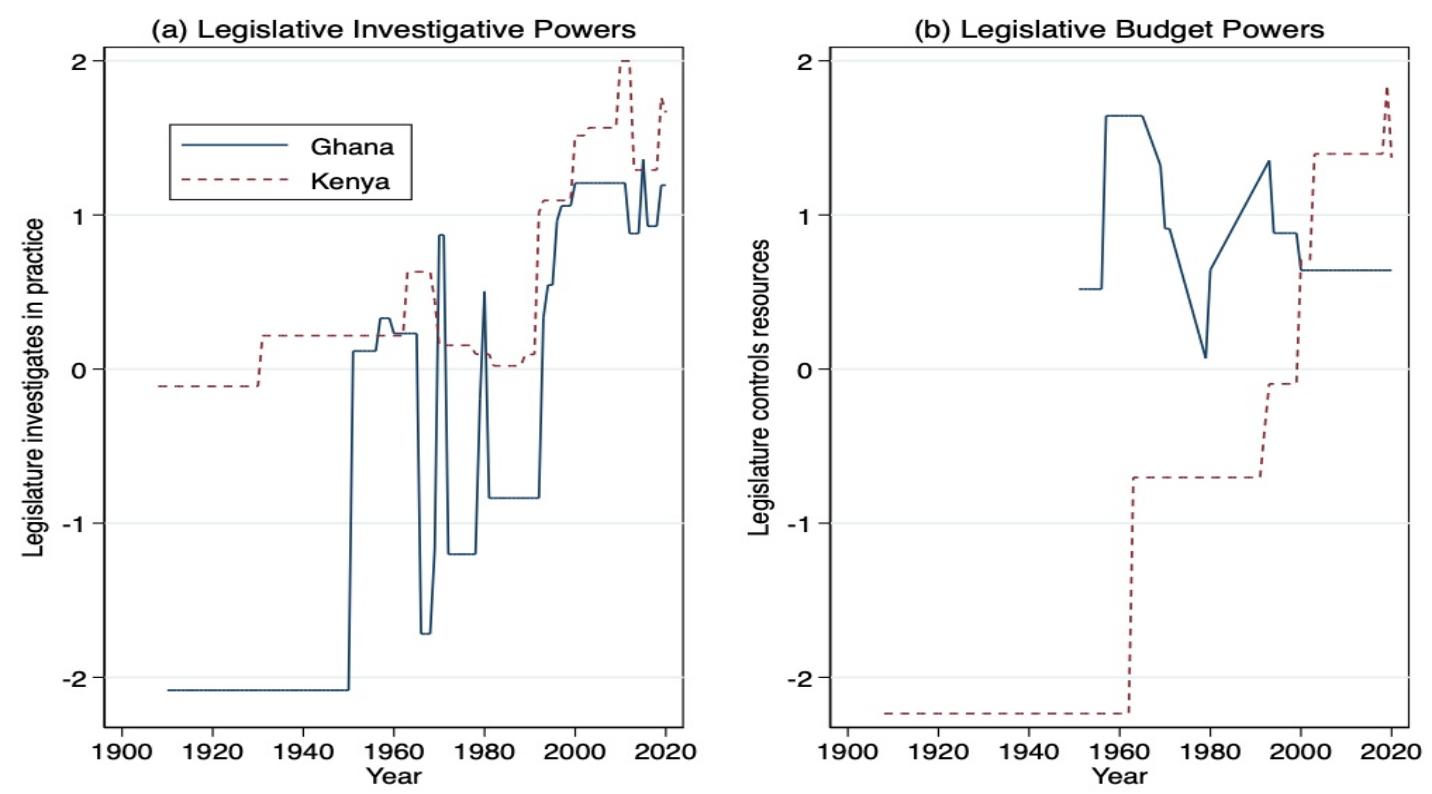

Notes: Figures show trends in legislative investigative powers (a) and legislative control over funds (b) in Ghana and Kenya. Notice the stepwise trends in legislative development in Kenya, in contrast to the volatility in Ghana. Data from Coppedge et al. (2021).

and Africans, with the moderates of either camp being part of the dominant coalition that achieved independence. After independence, the dominant coalition was incentivized to use the legislature as the main arena for organizing intra-elite politics. Unlike in Ghana where the critical juncture of decolonization planted seeds of instability, in Kenya it was marked by layering of African majority rule over the colonial institutional architecture. Thereafter Kenya's legislative institutional development was marked by relative stability, especially when compared to the Ghanaian legislature's volatility (Figures 4 and 5).

\subsection{Coalition Politics and Institutional Change}

This section employs analytical narratives and data from colonial Ghana and Kenya to describe the underlying mechanisms that drove their respective legislatures' institutional development. The data on legislative membership are from the Annual Reports from Colo- 
nial Africa in Official Statistics, 1821-1953 digital archives. ${ }^{22}$ I collected data on the date of appointment (and duration of tenure) of members of Legislative Councils and their status (Officials vs Unofficials). Where possible, I also collected data on the occupation of individual members. To capture legislative output, I collected data on annual counts of Ordinances passed, Orders in Council from the Crown in London, and instances of executive rule making by Governors. The latter include Orders, Legal Notices, Rules, and Proclamations. The number of Ordinances per year are indicative of legislatures' institutional effort and importance; while high levels of executive rule making indicate executive dominance.

According to the data on legislative membership and output, the Gold Coast LegCo looked stronger than its Kenyan counterpart on some measures but not others. Average tenure (Figure $6(\mathrm{a})$ ) and the number of Unofficials increased over time (Figure $6(\mathrm{~b})$ ). Similarly, the legislature passed more Ordinances over time, despite the regular spikes in instances of executive (Governor) rule making and Orders in Council from the Crown in London (Figure 7). The Kenyan LegCo's average tenure was actually decreasing over time. However, it produced about as much legislation as the Gold Coast and also saw the share of Unofficials increase after the 1930s (Figures 8 and 9). Kenya, too, had relatively higher levels of executive (Governor) rule making (relative to Ordinances). This is indicative of the fact colonial legislatures were inherently autocratic institutions dominated by Governors.

A key difference between the LegCos in the Gold Coast and Kenya was the nature of dominant factions in the two institutions over time. In the Gold Coast, temporal variation in the dominant factions (Merchants, Barristers, Chiefs, educated "Commoners" - in that order) within the LegCo inhibited the emergence of stable executive-legislative relations both before and after independence. In particular, the process of decolonization cast aside the historical institutionalist dominant coalition in favor of an outsider revisionist coalition. This resulted in a discontinuous institutional change at independence. Thus Ghana found itself on a path towards postcolonial legislative institutional volatility despite significant institutionalization

\footnotetext{
${ }^{22}$ See Kenya (East Africa Protectorate), 1901-1946 and Ghana (Gold Coast), 1846-1939.
} 
during the colonial era - as measured by increasing average tenure of members, increasing role of Unofficials, and rising number of Ordinances passed each year (Figures 6 and 7).

Kenya's LegCo took a different path. European Unofficials dominated the institution until the process decolonization increased African membership. Despite the decline in average tenure, the LegCo showed signs of institutionalization - as seen in the passage of more laws over time and increasing share of Unofficials (Figures 8 and 9). Decolonization was marked by splits in both the European and African factions in the LegCo, thereby resulting in multi-racial independence coalitions. The fact that moderates midwifed independence foreclosed on radical institutional change. The institutional layering at independence was most vividly illustrated by the fact that the last colonial Speaker of the Legislative Council (a European settler) stayed in his role for seven years after independence. Overall, the politics of decolonization in Kenya reinforced legislative institutional stability (Figures 4 and 5). ${ }^{23}$

\subsubsection{Factional Politics and Institutional Discontinuity in Ghana}

It is not an exaggeration to state that political development in colonial Ghana "can only be understood if viewed, in part, as a struggle between local and provincial chiefs against new, educated, 'westernized' African leaders for the allegiance of the people" (Drake, 1956, p. 78). At its founding, the Gold Coast LegCo existed to serve commercial interests (Kaplow, 1971; Bly, 1982; Doortmont, 2006; Asante, 2016). Until 1925 membership was by appointment. Unofficials were key drivers of institutional development. The first two Unofficials were merchants. In 1898 lawyers began to replace merchants. At around the same time, the administration came to view Chiefs as the legitimate representatives of Africans, thereby opening a rift between Chiefs and educated "Commoners" that would define intra-elite politics for decades to come. In 1911 the first Chief was appointed to the LegCo. Thereafter Chiefs dominated Gold Coast politics until the Convention People's Party (CPP) swept to

\footnotetext{
${ }^{23}$ See also Figure A4 in the Online Appendix.
} 
power in $1951 .{ }^{24}$ Initially, Unofficials represented Chiefs of the Gold Coast Colony, the towns of Accra, Cape Coast, and Sekondi, and merchants. In 1925 the LegCo acquired limited authority to legislate for Ashanti and the Northern territories. It was later expanded to include representatives for Kumasi and Ashanti Chiefs (1944) and the Northern Territories (1951).

Figure 6: Membership of the Gold Coast Legislative Council
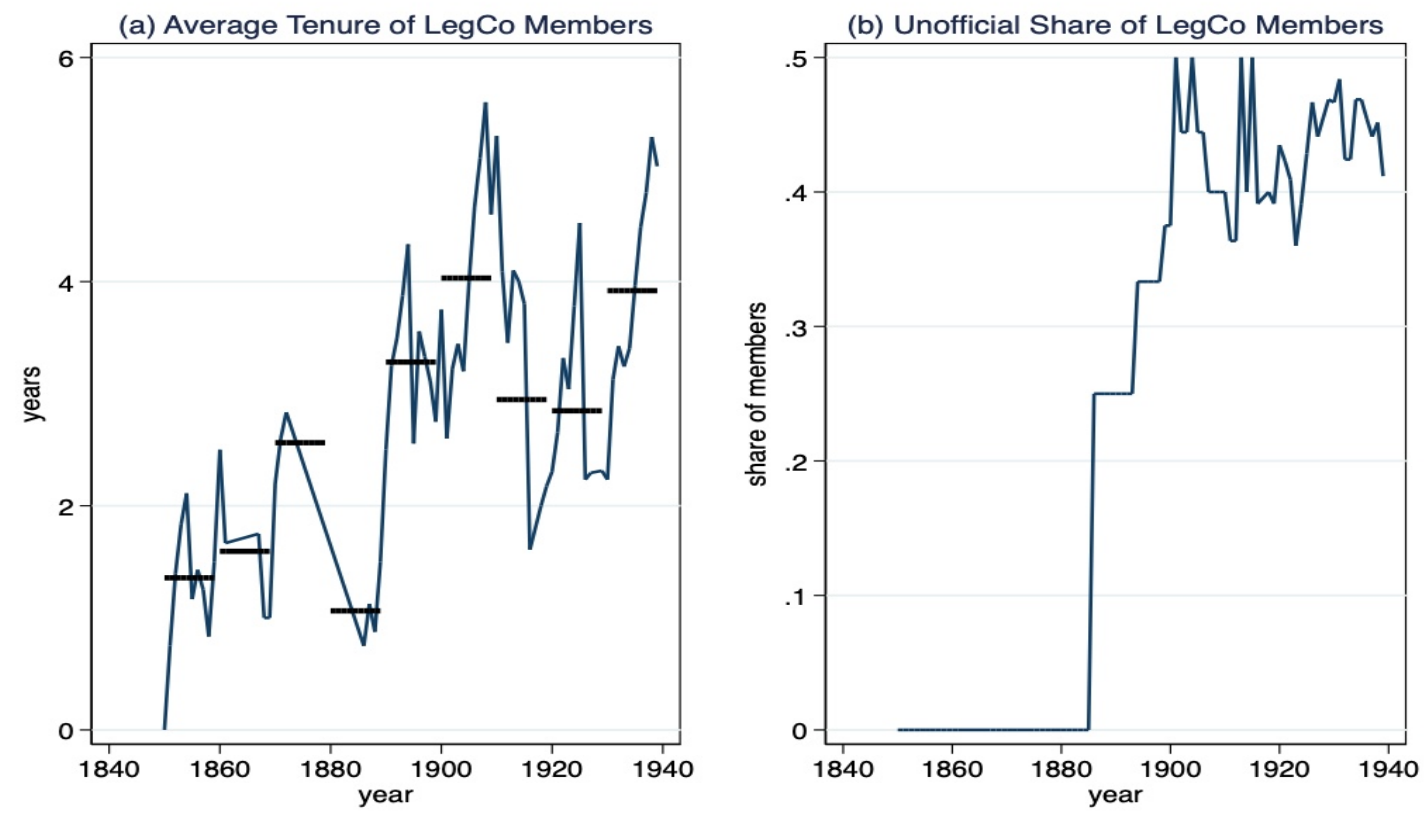

Notes: Figures show trends in the average tenure and the status of members in the Gold Coast Legislative Council. Horizontal lines indicate the average tenure per decade. Data from author.

For practical purposes, the LegCo functioned without "civilian" Unofficials until 1886. Between 1850 and 1886 its Unofficials also served in the Executive Council. The LegCo was closed between 1866 and 1874 when the colony was managed from Sierra Leone (Kimble, 1930). Proper Unofficials were appointed in 1886. From the outset Unofficials lobbied the administration over the question of elective representation - including by merchants (1850),

\footnotetext{
${ }^{24}$ By 1925 the administration "believed that it was chiefs, not the educated Africans, who represented the people" (Agbodeka, 1972, p. 60). While African merchants like James Bannerman, George Blankson, and Robert Hutchison dominated the LegCo the latter half of the 19th century, it was chiefs like Togbui Sri, Nana Amonoo, and Nana Ofori Atta that defined its early 20th century history. See Table A1 in the Online Appendix for a summary of the African members of the LegCo until 1926. See also Danquah (1928) on Chiefly authority and representation and Edsman (1979) on the role of lawyers in Gold Coast politics.
} 
Figure 7: Trends in Legislative Output in the Gold Coast

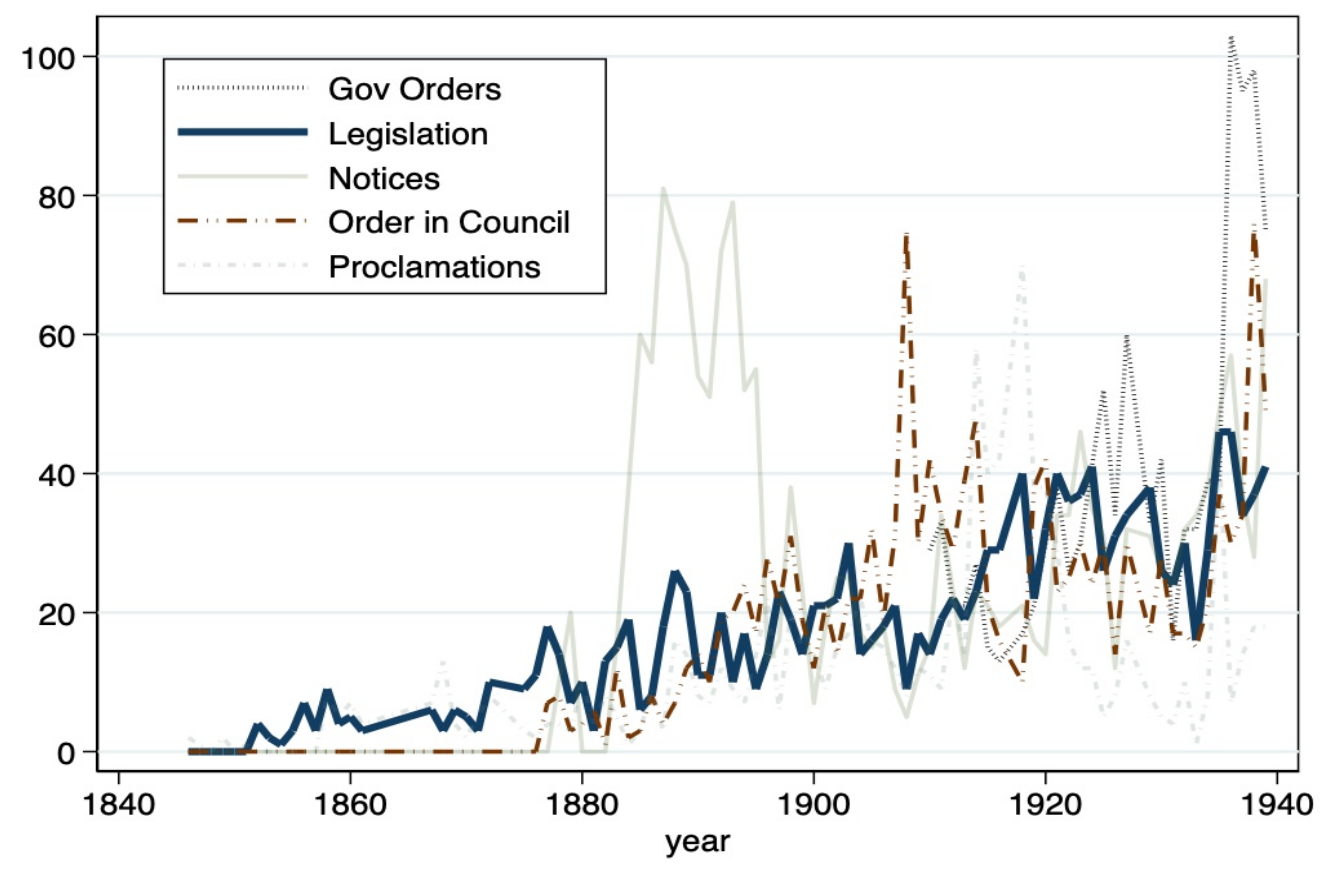

Notes: Figure shows trends in legislative outputs and executive rule making in the Gold Coast. Notice the high levels of Notices, Orders in Council and Governor's Orders relative to Kenya below. Data from author.

Chiefs (1898), and Educated Commoners (1918). ${ }^{25}$ Elective representation was introduced in $1925{ }^{26}$ While the LegCo was dominated by the Official majority, Unofficials could influence outcomes through extra-LegCo political pressure in the colony and in London. Most famously, the administration abandoned the Land Bill of 1897 after its passage in the LegCo due to political pressure (Omosini, 1972). In addition, after the creation of Provincial Councils (of Chiefs) in 1925, the administration consulted them before introducing legislation in the LegCo. Thus Chiefs acquired significant influence on the administration's legislative agenda.

Shifts in Unofficial factional politics threatened the LegCo's institutionalization. In the 19th century merchant Unofficials held the power and looked like they would be the foun-

\footnotetext{
${ }^{25}$ Following the annexation of Ashanti and the Northern Territories in 1901, the Legislative Council's jurisdiction extended to all three regions. However, the Governor retained much of the rule making powers outside of the Gold Coast Colony.

${ }^{26}$ Six representatives each for Chiefs' Provincial Councils and European Unofficials were elected by electoral colleges, while municipal members representing the urban areas of Accra, Cape Coast, and Sekondi were elected by a qualified direct franchise (on the basis of age and property).
} 
dation of African political development in the colony. However, they were soon upstaged by the newly educated Africans (mostly lawyers). The mobilization to oppose the 1897 Lands Bill gave birth to the Aborigines Rights Protection Society (ARPS), an entity that became recognized by the administration as the organized voice of Africans in the colony (Kimble, 1930; Edsman, 1979). Major constitutional changes in 1916, 1925, and 1946 upset this balance and redistributed power both within and outside the LegCo in favor of Chiefs (Wight, 1947; Firmin-Sellers, 2000). Under indirect rule, Chiefs effectively became the administrative arm of the colonial state (and local government) in rural areas. In 1925 Chiefs' Provincial Councils replaced the ARPS as the recognized voice of African interests, thereby rendering Chiefs' Councils and the Joint Provincial Council as the administration's chosen foundation upon which to build African political development. The influence of the new educated elites was restricted to urban areas (Danquah, 1994). ${ }^{27}$ When African majority (18 out 31 seats) in the LegCo was achieved in 1946, chiefs filled more than three quarters of African seats.

The defining intra-elite cleavage pitted those who preferred political modernization under the leadership of the new educated elites (majority of whom were "commoners") against those who preferred political development under indirect rule by the Chiefs. The administration sided with the Chiefs, the net result of which was to neutralize the political power of "elite commoners" (Apter, 1955). ${ }^{28}$ It took until 1947 for a new major African political party the United Gold Coast Convention (UGCC) - to be formed. The party was an alliance between educated professions and moderate Chiefs. It was gradualist and sought to reduce the role of Chiefs in politics. However, no sooner had the UGCC been formed than the 1948 Accra riots broke out - with disastrous political consequences for Chiefs. The riots forced a breakup of the UGCC, with the more radical politicians joining the newly formed (in

\footnotetext{
${ }^{27}$ Another organization, the National Congress of British West Africa (NCBWA) and various municipal organizations were formed in 1920 to champion issues of mostly educated urban residents (Eluwa, 1971). It, too, declined due to Chiefs' dominance and lack of rootedness in rural mass politics. In 1916 Chiefs were $3 / 12$ of Unofficials and 6/14 in 1925. When African majority was introduced in 1946 Chiefs controlled 9/18 seats (Bourret, 1949; Gocking, 2005).

${ }^{28}$ In 1944 chiefs' powers got a boost when native authorities became local governments (Austin, 1970).
} 
1949) Convention People's Party (CPP). It also precipitated a constitutional amendment that distributed power in the LegCo away from Chiefs.

While the UGCC was a coalition for institutional continuity in the LegCo, the CPP was not. Their only shared goal was the desire to curtail Chiefs' powers within the LegCo. The Coussey constitutional review process (1949) created the opportunity to achieve this objective. The UGCC "wanted to replace chiefs on the Legislative Council with "educated commoners," (Gocking, 2005, p. 85) and self-rule within the British empire "within the shorted possible time" (Danquah, 1994, p. 11). The CPP wanted immediate self-rule under commoners. As Rathbone (2000) notes, "[t]he modern elite which had pioneered nationalism in the Gold Coast had deeply resented the dominance of chiefs in the colonial councils of state..." (p. 21). ${ }^{29}$ Despite the moderate nature of the 1949 "Coussey Constitution," the CPP's surprise landslide victory in the 1951 elections put the LegCo on a completely different developmental trajectory. The party's rallying call that "chiefs no longer sit on Stools but on Gazettes" paid off. Under CPP Chiefs lost their representation in the LegCo; failed to realize an upper chamber for Chiefs; and were no longer consulted on legislation as was the norm under colonialism (Firmin-Sellers, 2000). Most importantly, from then onwards the CPP and not the legislature became the locus of managing intra-elite politics.

The Gold Coast LegCo may have been a century old in 1951, but its internal politics militated against continuity. The Chiefs' loss of power disrupted decades of institutional development. "[P[rior to the assumption of power by the CPP, [Chiefs and their councils were] the most important and powerful institution in the Gold Coast apart from the 'Governorin-Council'" (Frimpong, 1973, 79). Their crushing loss in 1951 swept away not only their power, but also the institutional architecture (Provincial Councils and the LegCo) that had underpinned decades-long political development. The CPP dominated the legislature, and was in turn dominated by its leader Kwame Nkrumah. After independence in 1957, Ghana

\footnotetext{
${ }^{29}$ The same was true of their supporters, the leading lights among them being elementary school graduates that were "persistent opponents of a native authority system which offered them no outlet for their energies" (Austin, 1970, p. 17)
} 
quickly switched from a parliamentary to presidential system (1960) and then imposed single party rule (1964). In 1965 the CPP simply appointed the new legislature without bothering to hold elections. A year later Nkrumah was deposed in a coup that launched a period of legislative institutional volatility and neglect that only ended with the return of democratic rule in the 1990s.

\subsubsection{Dominant Factions and Institutional Stability in Kenya}

Founded as an exclusively European institution in 1907, the history of the Kenyan LegCo provides a sharp contrast to that of Ghana. In the Gold Coast "the African cultivator and the African native ruler [held] the centre of the stage," while in Kenya "that place [was] assumed by 2000 settlers..." (Bertram, 1930, p. 195). In Ghana the Chiefs' dominance attracted opposition from educated "elite commoners", with the more radical elements of the latter emerging victorious in 1951. In Kenya, European settlers dominated the LegCo for much of the colonial period. ${ }^{30}$ By the 1920s the "European settler influence on government was so great that the official majority in the Legislative Council had ceased to have any meaning" (Bennett, 1963, p. 59). Kenya's "Local Native Councils" (established in 1924), unlike Ghana's Provincial Councils, had no direct influence on the LegCo. ${ }^{31}$

Unlike Ghana where the CPP shot to prominence virtually overnight in 1951, African incorporation in the Kenyan LegCo and progression to majority began in 1944 and took nine years. Furthermore, at independence the dominant African independence coalition was moderate and in an implicit alliance with the moderate European settlers (Wasserman, 1976; Opalo, 2019). Finally, in the independence settlement of 1963, both dominant African factions were accommodated in the constitution - thereby preserving broad-based elite support for

\footnotetext{
${ }^{30}$ Under Governor Edward Northey (1919-1922), relations between the administration and European settlers were cordial enough for the Governor to allow officials a free vote in the LegCo. Hugh Cholmondeley (Lord Delamere), a prominent settler, characterized the Northey era as "government by agreement"; while settlers more generally referred to the Governor as their "ambassador" (Bennett, 1963, p. 48-49).

${ }^{31}$ Initial African political mobilization in the 1920s did not yield any representation in the LegCo. Bans, arrests, and geographic/cross-ethnic restrictions on political mobilization stunted African political development through the late 1950 s.
} 
the constitutional order and centrality of the legislature as the locus of intra-elite distributive politics (Gertzel, 1970; Opalo, 2014).

Figure 8: Membership in the Kenyan Legislative Council
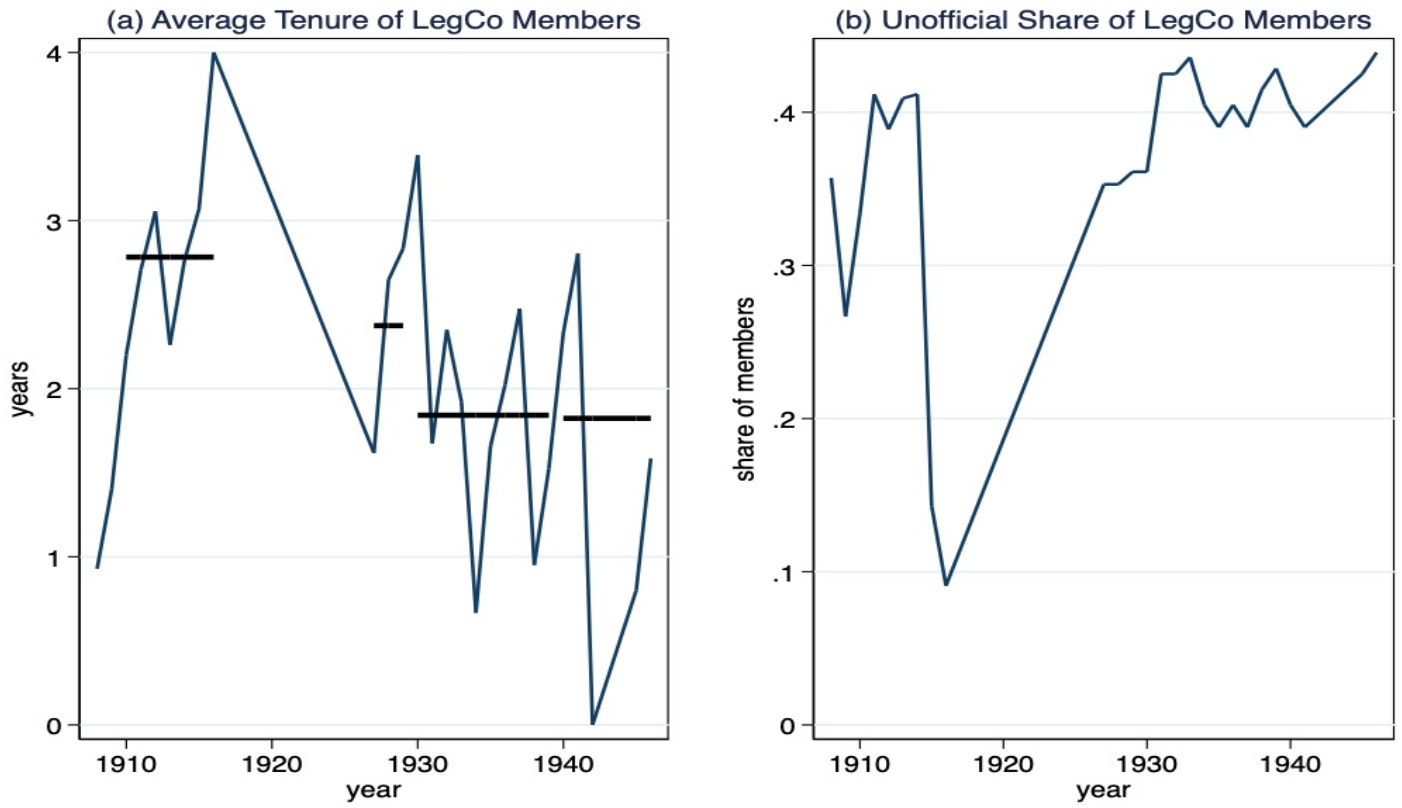

Notes: Figures show trends in the average tenure and the status of members in Kenya's Legislative Council. Data from author.

Like in Ghana, the colonial administration tried to establish indirect rule in Kenya. However, Kenya lacked strong pre-colonial polities (Ogot, 1963). Therefore, the Local Native Councils (LNCs) created in 1924 were a pale shadow of the Gold Coast's District and Provincial Councils. Despite their collaboration with the colonial administration (Wamagatta, 2016), Kenya's (mostly invented) Chiefs were never a powerful political force in the LegCo. African political development in the colony was largely driven by the new educated elites who focused their attention on achieving representation in the LegCo - a goal that was achieved in 1944 (Roelker, 1976). ${ }^{32}$ Before then appointed European missionaries purportedly represented African interests. Kenya also differed from Ghana in having a large

\footnotetext{
${ }^{32}$ Before the 1957 direct elections the Governor appointed Africans to the LegCo from a list of LNC nominees. However, these nominees were not agents of the LNCs, but aspiring national political leaders in their own right. Importantly, none of Kenya's LegCo members would be considered to represent "traditional" or chiefly interests.
} 
Figure 9: Trends in Legislative Output in Kenya Colony

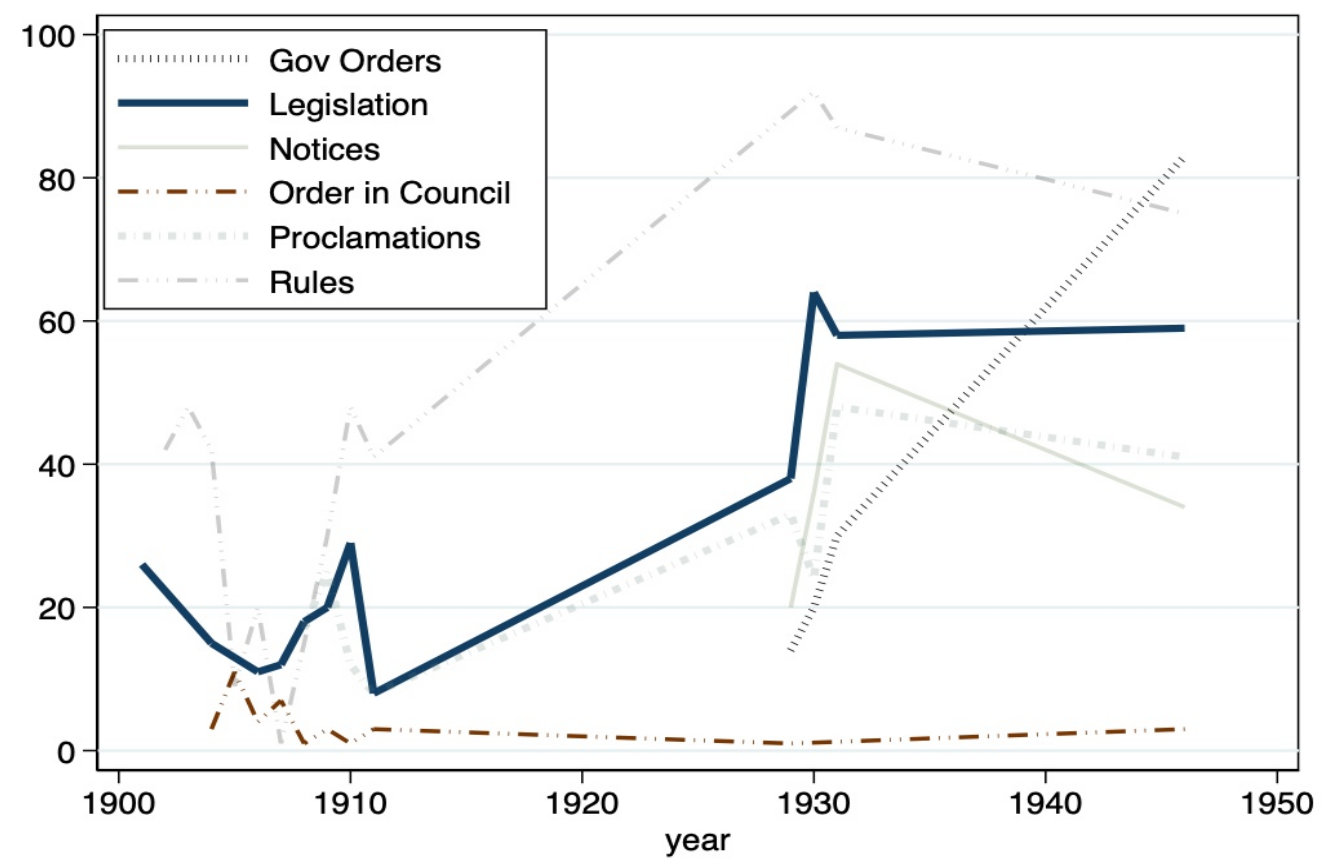

Notes: Figure shows trends in legislative outputs in Kenya. Notice the low levels of Orders in Council in Kenya as compared to Ghana above. Data from author.

Indian immigrant community. Indian representation in the LegCo began in 1910 after Alibhai Mulla Jeevanjee's appointment late 1909 (Bennett, 1963). Yet despite achieving earlier representation in the LegCo, the Devonshire Declaration in 1923 neutralized Indian political power by espousing the "paramountcy" of African interests in the colony (Ross, 1927; Izuakor, 1983). ${ }^{33}$ Thereafter the most important political cleavage was between Africans and Europeans. Among African politicians, the dominant faction favored institutionalized political development within the LegCo. ${ }^{34}$ The same was true for Europeans who wanted minority self-rule.

For 50 years, the dominant European faction in the LegCo was institutionalist - with the

\footnotetext{
${ }^{33}$ The Devonshire Declaration was largely symbolic, since the colonial government had no intention of preventing unjust European exploitation of African labor and lands. However, it had the material effect of stalling the advancement to minority rule as happened in the settler colonies of southern Africa and prevented the consolidation of Indian political power within and outside the LegCo (despite Indians' numerical superiority over Europeans).

${ }^{34}$ See Hakes (1970); Roelker (1976); Wasserman (1976); Maloba (2018) and Opalo (2019).
} 
goal of achieving responsible government under minority rule. From the outset, the "fundamental conflict between the settlers and the bureaucracy concerned whether the Legislative Council would have majority Unofficials" (Hakes, 1970, p. 6). As early as 1908 Europeans organized themselves in a Convention of (district) Associations to press for their interests in Nairobi and London. ${ }^{35}$ The Convention became known as the "Settlers' Parliament" and "exerted influence far beyond any other Unofficial organization" in the colony (Dilley, 1966, p. 41). Elective representation was achieved in 1920 and Unofficial majority in 1948. Yet by 1948 half of Unofficials were non-Europeans. Over time, economic differentiation precipitated a divergence of interests among Europeans. Most rural farmers wanted minority self-rule, while non-farm settlers favored a multiracial African majority rule. The relative financial dominance of the latter group earned them support from the colonial administration (Bennett, 1963; Ghai and McAuslan, 1970; Wasserman, 1976). In 1945 Alfred Vincent (businessman) replaced Francis Scott (farmer) as the voice of Europeans in the colony.

Table 6: Number of Legislative Sittings Immediately After Independence

\begin{tabular}{l|c|c|c|c|c}
\hline Year & Ghana & Kenya & Nigeria & Tanzania & Uganda \\
\hline First Year & 85 & 90 & 44 & 34 & 92 \\
Second Year & 87 & 95 & 54 & 29 & 83 \\
Third Year & 94 & 106 & 41 & 26 & 83 \\
Fourth Year & 97 & 119 & 32 & N/A & 58 \\
Fifth Year & 85 & 136 & 32 & N/A & 87 \\
\hline
\end{tabular}

Notes: Table shows the number of sittings in early postcolonial legislatures in a number of former British colonies. Notice the difference in the number of sittings between Kenya and Ghana. Data from Hakes (1970).

African political development in Kenya was broadly motivated by the question of a fair representation in the LegCo. Initially, the expansion was gradual and through appointment. However, the Mau Mau rebellion increased the bargaining power of nationalists calling for elective representation - which was realized in 1956. The first elected Africans joined the

\footnotetext{
${ }^{35}$ By 1919 there were about 42 European associations. Founder members of the Convention (1910) were the Colonists/Planters and Farmers and Pastoralists Associations (Atieno-Odhiambo, 1981).
} 
LegCo in 1958 after which the progression to African majority rule accelerated. The 1961 elections brought about African majority in the LegCo under the Kenya African National Union (KANU). The other major African party was the Kenya African Democratic Union (KADU). KANU was implicitly allied with European moderates. KADU's interests were aligned with those of settler farmers. The independence constitutional compromise accommodated both camps, with KADU compensated with a regionalist government designed to protect smaller ethnic groups, a bicameral legislature, and strong constitutional constraints on executive power (Proctor, 1965; Stultz, 1969; Anderson, 2005). ${ }^{36}$

Kenya gained independence in 1963 under a dominant faction that broadly respected the idea of parliamentary supremacy. The legislature's importance was further enhanced by the weakness of the ruling party (Gertzel, 1970; Hakes, 1970). Unlike in Ghana where the CPP emerged as a substitute to the legislature, in Kenya parliament was the main locus of intraelite politics. This is partially illustrated by the fact that the early postcolonial legislature held significantly more meetings per year than its counterparts in the region (Table 6). Since the dominant faction in the legislature was always institutionalist, broad-based recognition of the institution's importance granted it stability and relevance even after revisions of the independence settlement and Kenya's descent into single party rule (Opalo, 2019). ${ }^{37}$

\section{Conclusion}

A large literature explores the long-run impacts of colonial institutions. These works typically examine broadly defined institutional features of colonialism and link them to contemporary outcomes. This article contributes to this literature by examining a specific colonial institution over time. First, I use cross-country data on measures of legislative strength to show that the link between colonial institutional design and contemporary outcomes is tenuous at best

\footnotetext{
${ }^{36}$ The settlement was dissolved in 1966, but after the absorption of KADU into KANU (Nyong'o, 1989).

${ }^{37}$ It is telling that, as documented by Opalo (2019) and Widner (1992), Kenya's legislature survived even attempts by President Daniel Moi to use KANU as a substitute for the party.
} 
and sensitive to measurement. Second, through a comparative study of Ghana and Kenya, I show that their shared colonial institutional origins notwithstanding, the two countries' legislatures diverged on account of the nature of their internal factional politics.

Despite being an archetypical "extractive colony," Ghana's colonial legislature had African representation from the outset and was better integrated into its political economy. Kenya was a "settler colony" whose legislature was dominated by European immigrants. African representation only came about in 1944. Yet it was Ghana that experienced postcolonial legislative institutional instability and not Kenya. I argue that the two legislatures' institutional divergence was driven by their respective membership and the resulting factional politics. In Kenya, stable dominant factions (whether African or European) were predominantly institutionalist and incentivized to position the legislature as the main forum for managing intra-elite politics. In Ghana, shifting African coalitions of merchants, barristers, chiefs, and populist "commoners" had competing conceptions of the role of the legislature. While Chiefs were dominant between 1925 and 1951, they eventually lost power (and LegCo membership) to the CPP. The CPP then relocated the locus of intra-elite bargaining from the legislature to the ruling party. Thus the stage was set for the four-decade postcolonial institutional instability and decline of the Ghanaian legislature.

The results herein call for more research on the temporal evolution of colonial institutions. In explaining institutional persistence and/or change, such research should pay close attention to how colonial and postcolonial institutional design structured political development and the distribution of power among key political players. This article also shows the importance of measurement in historical institutionalism research. Focusing on specific colonial institutions (like legislatures or judiciaries), as opposed to broadly defined institutional regimes, will allow us to collect data on temporally-consistent measures of institutional features, processes, and outcomes. Doing so will greatly enhance our understanding of the specific mechanisms behind colonial institutional persistence and change. 


\section{References}

Abad, Letitia A. and Noel Maurer. 2021. "History Never Really Says Goodbye: A Critical Review of the Persistence Literature." Journal of Historical Political Economy 1:31-68.

Acemoglu, Daron, Simon Johnson and James Robinson. 2001. "The Colonial Origins of Comparative Development." American Economic Review 91:1369-1401.

Agbodeka, Francis. 1972. African Politics and British Policy in the Gold Coast, 1868-1900: a study in the forms and force of protest. London, UK: Longmans.

Alesina, Alberto, Arnaud Devleeshauwer, William Easterly, Sergio Kurlat and Romain Wacziarg. 2003. "Fractionalization." Journal of Economic Growth 8:155-194.

Allman, Jean Marie. 1993. The Quills of the Porcupine: Asante Nationalism in an Emergent Ghana. Madison, Wisconsin: University of Wisconsin Press.

Anderson, David M. 2005. "Yours in Struggle for Majimbo: Nationalism and the Party Politics of Decolonization in Kenya, 1955-64." Journal fo Contemporary History 40(3):547564.

Apter, David E. 1955. Ghana in Transition. Princeton, NJ: Princeton University Press.

Arhin, Kwame. 1985. "Chieftaincy Under Kwame Nkrumah." Paper Presented at the Symposium of the Life and Work of Kwame Nkrumah, Instute of African Studies, University of Ghana.

Asante, Kofi Takyi. 2016. 'Purchased allies' or 'thorns in the side of the government'?: African Merchants and Colonial State Formation in the Nineteenth Century Gold Coast PhD thesis Northwestern University' Evanston, Ill: .

Atieno-Odhiambo, Elisha Stephen. 1981. Siasa: Politics and Nationalism in East Africa, 1905-1939. Nairobi, Kenya: Kenya Literature Bureau.

Austin, Dennis. 1970. Politics in Ghana, 1946-1960. Oxford, UK: Oxford University Press.

Bennett, George. 1963. Kenya: A Political History, The Colonial Period. Oxford, UK: Oxford University Press.

Bertram, Anton. 1930. The Colonial Service. Cambridge, UK: Cambridge University Press.

Bly, Viola Mattavous. 1982. The British Presence and Its Influence on Indigenous Gold Coast Economics (1865-1902) PhD thesis New York University New York, NY: .

Bockstette, Valerie, Areendam Chanda and Louis Putterman. 2002. "States and Markets: The Advantage of an Early Start." Journal of Economic Growth 7:347-369.

Bolton, Alexander and Sharece Thrower. 2016. "Legislative Capacity and Executive Unilateralism." American Journal of Political Science 60(3):649-663. 
Bourret, F. M. 1949. The Gold Coast: A Survey of the Gold Coast and British Togoland, 1919-1946. Stanford, CA: Stanford University Press.

Burns, Alan, ed. 1966. Parliament as an Export. London, UK: George Allen and Unwin.

Cartwright, John R. 1970. Politics in Sierra Leone: 1947-67. Toronto, Canada: University of Toronto Press.

Cheibub, Jose Antonio, Jennifer Gandhi and James Raymond Vreeland. 2010. "Democracy and Dictatorship Revisited." Public Choice 143(2):67-101.

Cooper, Frederick. 2014. Citizenship Between Empire and Nation: Remaking France in French Africa, 1945-1960. Princeton, NJ: Princeton University Press.

Coppedge, Michael, John Gerring, Carl Henrik Knutsen, Staffan I. Lindberg, Jan Teorell, Vlad Ciobanu and Lisa Gastaldi. 2021. "V-Dem Country Coding Units v11." Varieties of Democracy Project.

Danquah, Francis. 1994. "Rural Discontent and Decolonization in Ghana, 1945-1951." Agricultural History 68(1):1-19.

Danquah, Joseph B. 1928. The Akim Abuakwa Handbook. London, UK: Forster Groom and Co. Ltd.

Davidson, James Wightman. 1974. The Northern Rhodesia Legislative Council. London, UK: Greenwood Press.

Dilley, Marjorie Ruth. 1966. British Policy in Kenya Colony. London, UK: Frank Cass and Co. Ltd.

Doortmont, Michel R. 2006. "Producing a Received View of Gold Coast Elite Society? C. F. Hutchison's 'Pen Picture of Modern Africans and African Celebrities'." History of Africa 33:473-493.

Drake, St. Clair. 1956. "Prospects for Democracy in the Gold Coast." Annals of the American Academy of Political and Social Science 306:78-87.

Edsman, Björn M. 1979. Lawyers in Gold Coast Politics c. 1900-1945 PhD thesis University of Uppsala Uppsala, Sweden: .

Egerton, H. E. 1918. "The System of British Colonial Administration of the Crown Colonies in the Seventeenth and Eighteenth Centuries Compared with the System Prevailing in the Nineteenth Century." Transactions of the Royal Historical Society 1:190-217.

Eluwa, G I C. 1971. "Background to the Emergence of the National Congress of British West Africa." African Studies Review 14(2):205-218. 
Fioretos, Orfeo, Tulia G. Falleti and Adam Sheingate. 2016. Historical Institutionalism in Political Science Historical Institutionalism in Political Science Historical Institutionalism in Political Science. In Oxford Handbook of Historical Institutionalism, ed. Orfeo Fioretos, Tulia G. Falleti and Adam Sheingate. Oxford, UK: Oxford University Press chapter 1.

Firmin-Sellers, Kathryn. 2000. "Institutions, Context, and Outcomes: Explaining French and British Rule in West Africa." Comparative Politics 32(3):253-272.

Fish, M. Steven and Matthew Kroenig. 2009. The Handbook of National Legislatures: A Global Survey. Cambridge, UK: Cambridge University Press.

Fletcher-Cooke, John. 1966. Parliament, The Executive, and the Civil Service. In Parliament as an Export, ed. Alan Burns. London, UK: George Allen and Unwin chapter 6, pp. 142165.

Frimpong, Kofi. 1973. "Joint Provincial Council of Paramount Chiefs and the Politics of Independence, 1946-58." Transactions of the Historical Society of Kenya 14(1):79-91.

Gertzel, Cherry. 1970. The Politics of Independent Kenya. Nairobi, Kenya: East African Publishing House.

Ghai, Yash Pal and J. P. W. B. McAuslan. 1970. Public Law and Political Change in Kenya. Oxford, UK: Oxford University Press.

Gocking, Roger S. 2005. The History of Ghana. London, UK: Greenwood Press.

Grzymala-Busse, Anna. 2011. "Time Will Tell? Temporality and the Analysis of Causal Mechanisms and Processes." Comparative Political Studies 44(9):1267-1297.

Hakes, Jay E. 1970. The Parliamentary Party of the Kenya African National Union Thesis Duke University Durham, NC: .

Hall, Peter A. 2009. Historical Institutionalism in Rationalist and Sociological Perspective. In Explaining Institutional Change: Ambiguity, Agency, and Power, ed. James Mahoney and Kathleen Thelen. Cambridge, UK: Cambridge University Press chapter 7, pp. 204-224.

Hall, Peter A. 2016. Politics as a Process Structured in Space and Time. In The Oxford Handbook of Historical Institutionalism, ed. Orfeo Fioretos, Tulia G. Falleti and Adam Sheingate. Oxford, UK: Oxford University Press chapter 2.

Hariri, Jacob Gerner. 2012. "The autocratic legacy of statehood." American Political Science Review 106(3).

Hayward, Fred M. 1984. "Political Leadership, Power and the State: Generalizations From the Case of Sierra Leone." African Studies Review 27(3):19-39.

Heston, Alan, Robert Summers and Bettina Aten. 2002. "Penn World Table Verson 6.3." Center for International Comparisons at the University of Pennsylvania (CICUP). 
Huntington, Samuel P. 1965. "Political Development and Political Decay." World Politics $17(3): 386-430$.

Izuakor, Levi I. 1983. "Kenya: The Unparamount African Paramountcy, 1923-1939." Transafrican Journal of History 12:33-50.

James, Cyril Lionel Robert. 1938. The Black Jacobins: Toussaint L'Ouverture and the San Domingo Revolution. 2 ed. New York, NY: Dial.

Juan, Alexander De and Jan Henryk Pierskalla. 2017. "The Comparative Politics of Colonialism and Its Legacies: An Introduction." Politics and Society 45(2):159-172.

Kaplow, Susan Beth. 1971. African Merchants of the Nineteenth Century Gold Coast PhD thesis Columbia University New York: .

Kimble, David. 1930. A Political History of Ghana: The Rise of the Gold Coast Nationalism, 1850-1928. Oxford, UK: Clarendon Press.

Kiwanuka, M Semakula. 1970. "Colonial Policies and Administrations in Africa: The Myths of the Contrasts." African Historical Studies 3(2):295-315.

Lankina, Tomila and Lullit Getachew. 2012. "Mission or Empire, Word or Sword? The Human Capital Legacy in Postcolonial Democratic Develop- ment." American Journal of Political Science 56(2):465-83.

Lee, Alexander and Jack Paine. 2019. "British colonialism and democracy: Divergent inheritances and diminishing legacies." Journal of Comparative Economics 47(3):487-503.

Lewis, Martin Deming. 1962. "One Hundred Million Frenchmen: The "Assimilation" Theory in French Colonial Policy." Comparative Studies in Society and History 4(2):129-153.

Mahoney, James and Kathleen Thelen, eds. 2010. Explaining Institutional Change: Ambiguity, Agency, and Power. Cambridge, UK: Cambridge University Press.

Maloba, W O. 2018. Kenyatta and Britain: An Account of Political Transformation, 19291963. New York, NY: Palgrave MacMillan.

Mamdani, Mahmood. 1996. Citizen and Subject: Contemporary Africa and the Legacy of Late Colonialism. Princeton, NJ: Princeton University Press.

Marshall, Monty G. and Keith Jaggers. 2009. Polity IV Project: Political Regime Characteristics and Transitions, 1800-2008. Boulder, CO: Technical Report, Center for Systemic Peace and Colorado University.

Morgenthau, Ruth S. 1964. olitical Parties in French-Speaking West Africa. Oxford, UK: Oxford Clarendon Press. 
Nyong'o, Peter Anyang'. 1989. "State and Society in Kenya: The Distintegration of the Nationalist Coalitions and the Rise of Presidential Authoritarianism 1963-78." African Affairs 88(351):229-251.

Ogot, Bethwell A. 1963. "British Administration in the Central Nyanza District of Kenya, 1900-60." Journal of African History 4(2):249-273.

Omosini, Olufemi. 1972. "The Gold Coast Land Question: 1894-1900: Some Issues Raised on West Africa's Economic Development." International Journal of African Historical Studies $5(3): 453-469$.

Opalo, Ken Ochieng'. 2019. Legislative Development in Africa: Politics and Post-Colonial Legacies. Cambridge, UK: Cambridge University Press.

Opalo, Ken Ochieng'. 2020. "Constrained Presidential Power in Africa? Legislative Independence and Executive Rule Making in Kenya, 1963-2013." British Journal of Political Science 50(4):1341-1358.

Opalo, Kennedy Ochieng'. 2014. "The Long Road to Institutionalization: The Kenyan Legislature and the 2013 Elections." Journal of Eastern African Studies 8(1):63-77.

Owolabi, Olukunle P. 2015. "Literacy and Democracy Despite Slavery: Forced Settlement and Postcolonial Outcomes in the Developing World." Comparative Politics 36(43-78).

Paine, Jack. 2019. "Democratic Contradictions in European Settler Colonies." World Politics 71(3):542-585.

Pierson, Paul. 2004. Politics in Time. Princeton, NJ: Princeton University Press.

Polsby, Nelson W. 1968. "The Institutionalization of the U.S. House of Representatives." American Political Science Review 62:144-168.

Porta, Roberto La, F. Lopez de Salinas and Andrei Shleifer. 2008. "The Economic Consequences of Legal Origins." Journal of Economic Literature 46:285-332.

Proctor, J. H. 1965. "The role of the Senate in the Kenya Political System." Parliamentary Affairs 18(4):389-415.

Rathbone, Richard. 2000. Nkrumah and The Chiefs: The Politics of Chieftaincy in Ghana, 1951-60. Athens, OH: Ohio University Press.

Roelker, Jack R. 1976. Mathu of Kenya: A Political Study. Hoover Colonial Studies Stanford, CA: Hoover Institution Press.

Ross, William McGregor. 1927. Kenya From Within: A Short Political History. London, UK: Routledge.

Rotberg, Robert I. 2008. "The Federation Movement in British East and Central Africa, 1890-1953." Journal of Commonwealth Political Studies 2(2):141-160. 
Sheingate, Adam. 2014. "Institutional Dynamics and American Political Development." Annual Review of Political Science 17:461-477.

Squire, Peverill. 2012. The Evolution of American Legislatures: Colonies, Territories and States, 1619-2009. Ann Arbor, MI: University of Michigan Press.

Stasavage, David. 2003. Public Debt and the Birth of the Democratic State: France and Great Britain, 1688-1789. Cambridge, UK: Cambridge University Press.

Stultz, Newell M. 1969. "Parliament in a Tutelary Democracy: A Recent Case in Kenya." Journal of Politics 31(1):95-118.

Swenson, Peter. 2001. Capitalists against Markets. Oxford, UK: Oxford University Press.

Thelen, Kathleen. 2004. How Institutions Evolve: The Political Economy of Skills in Germany, Britain, the United States and Japan. New York, NY: Cambridge University Press.

Thelen, Kathleen. 2014. Varieties of Liberalization and The New Politics of Social Solidarity. Cambridge, UK: Cambridge University Press.

Wamagatta, Evanson N. 2016. Controversial Chiefs in Colonial Kenya: The Untold Story of Senior Chief Waruhiu Wa Kung'u, 1890-1952. New York, NY: Lexington Books.

Wasserman, Gary. 1976. Politics of Decolonization: Kenya Europeans and the Land Issue, 1960-1965. Number 17 in "African Studies" Cambridge University Press.

Watson, M. 1995. "The British West Indian legislatures in the seventeenth and eighteenth centuries: An historiographical introduction." Parliamentary History 14(1):89-.

Wheare, Joan. 1950. The Nigerian Legislative Council. Oxford, UK: Faber and Faber.

Widner, Jennifer. 1992. The Rise of a Party-State in Kenya: From Harambee! to Nyayo! Berkeley, CA: University of California Press.

Wight, Martin. 1946. The Development of the Legislative Council, 1606-1945. Oxford, UK: Faber and Faber.

Wight, Martin. 1947. The Gold Coast Legislative Council. Oxford, UK: Faber and Faber.

Wrong, Hume. 1923. Government of the West Indies. Oxford, UK: Clarendon Press.

Wylie, Diana. 1977. "Confrontation Over Kenya: The Colonial Office and Its Critics, 19181940." Journal of African History 18(3):427-447. 